\title{
THE POLITICAL PARTICIPATION OF THE INDIGENOUS MUSLIM COMMUNITY IN LABUAN DURING THE BRITISH ADMINISTRATION, 1946-1963
}

\author{
PENGLIBATAN POLITIK KOMUNITI PERIBUMI ISLAM DI LABUAN SEMASA \\ ZAMAN PENJAJAHAN BRITISH, 1946-1963
}

\author{
Juwita Kumala Anak Robin \\ Institut Pengajian Borneo, Universiti Malaysia Sarawak \\ Kota Samarahan, Malaysia
}

Arnold Puyok

Fakulti Sains Sosial, Universiti Malaysia Sarawak

Kota Samarahan, Malaysia

* Corresponding author

Email address: yenchenkumala@ymail.com

\begin{abstract}
The theme of the political participation of the indigenous Muslim community in Labuan is important to fill the gap in Labuan's political history. The main questions which the study aimed to answer were: what political roles did the indigenous Muslim community play during the British colonial period from 1946-1963 in Labuan? What were the factors contributing to their political involvement and what were the reactions of the British? The study's three main objectives were: to describe the political participation of the indigenous Muslim community in Labuan from the period of 1946-1963, to analyse their roles in the British colonial administration, and to examine the British policy towards the involvement of the Muslim leaders in the political process. The study was mainly carried out through qualitative approach, involving archival research and in-depth interviews. Internal and external criticism methods were also applied in assessing, interpreting and analysing the primary, secondary and oral sources. All the key themes were presented in descriptive and chronological manner. The political participation of the indigenous Muslim community in Labuan can be divided into two phases: the first phase from 1946-1960 and the second phase, from 1961-1963. During the first phase, their political participation was essentially driven by their desires to safeguard their religious rights (Islam), ethnic identity and their collective ethnic interests. Throughout the second phase, the indigenous Muslim leaders were motivated by the Muslim community's political rights and Labuan's independence under the Malaysia proposal. The British attitudes towards the increased political awareness among the indigenous Muslim community leaders were generally accommodative. The indigenous Muslim community leaders were given opportunities to take part in the political activities. However, the political participation of the indigenous Muslim community was rather limited as Muslim leaders were incapacitated from playing greater political roles in the British colonial administration.
\end{abstract}

Keywords: political participation, indigenous Muslim community, Labuan, British, Malaysia. 


\begin{abstract}
ABSTRAK
Tema kajian berkenaan penglibatan politik komuniti peribumi Islam di Labuan penting dalam mengisi kelompangan sejarah politik Labuan. Persoalan-persoalan kajian yang cuba dijawab adalah: apakah peranan politik yang dimainkan oleh komuniti peribumi Islam semasa zaman penjajahan British, 19461963? Apakah faktor-faktor yang mempengaruhi penglibatan mereka dalam arena politik Labuan dan bagaimana pula reaksi British terhadap penglibatan tersebut? Tiga objektif utama kajian adalah: menghuraikan penglibatan komuniti peribumi Islam dalam arena politik Labuan dari tahun 1946-1963, menganalisis peranan yang dimainkan oleh komuniti peribumi Islam dalam pemerintahan kolonial British dan menilai dasar pihak British terhadap penglibatan politik pemimpin-pemimpin komuniti peribumi Islam. Kajian ini menggunakan pendekatan kualitatif yang melibatkan pengumpulan data melalui perpustakaan konvensional (sumber arkib) dan temu bual mendalam. Kaedah kritikan dalaman dan luaran turut diaplikasikan dalam menilai, menginterpretasi dan menganalisis sumber-sumber primer, sekunder dan lisan yang diperolehi. Tema-tema utama kajian pula dihuraikan secara deskriptif dan kronologikal. Dapatan kajian mendapati bahawa penglibatan peribumi Islam dalam arena politik Labuan dapat dibahagikan dalam dua fasa iaitu fasa pertama pada tahun 1946-1960 dan fasa kedua pada tahun 1961-1963. Penglibatan komuniti peribumi Islam dalam politik pada fasa pertama dipengaruhi oleh keinginan untuk memperjuangkan agama Islam, hak identiti etnik, dan kepentingan etnik kolektif komuniti peribumi Islam di Labuan. Manakala, pada fasa kedua pula, penglibatan politik komuniti peribumi Islam dimotivasikan oleh perjuangan untuk mendapatkan hak berpolitik dan tuntutan kemerdekaan dalam gagasan Malaysia. Didapati bahawa British bersifat terbuka terhadap kesedaran berpolitik yang ditunjukkan oleh pemimpin-pemimpin komuniti peribumi Islam. Peluang juga diberikan kepada pemimpin-pemimpin peribumi Islam di Labuan untuk terlibat dalam aktiviti berpolitik. Namun, penglibatan politik komuniti peribumi Islam di Labuan adalah terhad kerana pemimpin-pemimpin komuniti peribumi Islam tidak diberikan peranan yang signifikan dalam pentadbiran British.
\end{abstract}

Kata kunci: penglibatan politik, komuniti peribumi Islam, Labuan, British, Malaysia.

\title{
PENDAHULUAN
}

\section{Latar Belakang Kajian terhadap Peribumi (Islam)}

Penyelidikan berkenaan dengan 'peribumi' (dalam aspek peranan, penglibatan dan kedudukan), khususnya dalam pentadbiran dan politik di Malaysia dalam jangka masa sebelum dan selepas kedatangan penjajah, sehinggalah ke arah pembentukan dan kewujudan Malaysia, sememangnya sudah lama mendapat perhatian pengkaji daripada pelbagai bidang, khususnya bidang Sejarah, Sosiologi dan Sains Politik. Trend atau tema kajian sebegini wujud atas kesedaran pentingnya peranan golongan tersebut dalam perkembangan institusi pentadbiran dan politik negara, selain pengaruh daripada kepimpinan penjajah. Selain itu, jika dilihat dari sudut bidang Sejarah pula, kajian berkaitan dengan peribumi juga dianggap penting, sebagai sumbangan terhadap 'Sejarah Dari Bawah' yang tidak cenderung kepada penyelidikan yang bersifat 'Western Centric', sepertimana yang dapat diteliti daripada karya-karya yang dihasilkan oleh kebanyakan pengkaji dalam dan luar negara (Salleh \& Tan, 1996).

Melihat kepada skop yang lebih luas, asas kepada kajian yang memberikan tumpuan kepada 'peranan peribumi' datangnya daripada latar belakang kepulauan Borneo itu sendiri, yang mempunyai pelbagai pengalaman istimewa dalam aspek politik dan sosioekonomi akibat daripada penjajahan. Penting untuk melihat kembali sejarah awal sistem politik dan pentadbiran di Borneo, sebelum melihat signifikan dan relevannya kajian terhadap kepentingan penglibatan peribumi ini. (Husin \& Ariff, 2007:1) Transformasi yang jelas dapat dilihat, pada zaman sebelum dan selepas kedatangan Barat 
(khususnya British) ke Borneo semenjak abad ke-16. Sistem politik tradisional iaitu sebelum kedatangan penjajah sinonim dengan kekuasaan raja atau sultan sebagai pemerintah mutlak, yang dibantu oleh golongan pembesar peribumi dalam pelaksanaan pentadbiran dan politik dalam pemerintahan. Kedatangan Barat kemudiannya melunturkan sistem tradisional ini di mana, penguasaan pentadbiran dan politik didominasi oleh Gabenor, Pegawai Penasihat, Residen dan wakil kolonial yang kesemuanya merupakan bukan peribumi, yang berhubung secara langsung atau tidak langsung dengan pejabat pusat di negara asal. (Osman, et al, 1995)

Sebelum kedatangan Barat, antara kerajaan ulung yang menguasai banyak kawasan dan wilayah di Borneo adalah seperti kerajaan Srivijaya, Sumatera dari abad ke-7 Masihi sehinggalah 11 Masihi, (Shaffer, 1966:42) kerajaan Majapahit di Jawa sekitar tahun 1293 Masihi hingga 1500 Masihi, (Fic, 2003:49) Melaka dalam tahun 1400 hingga 1511 (Dollah, 1997:64) dan kerajaan Brunei yang wujud sekitar abad ke-7 atau ke-8 Masihi. (Schelander, 1998:32) Sistem politik monarki yang diamalkan kesemua kerajaan ini mempunyai persamaan yang signifikan. Agama dan kepercayaan turut sama memainkan peranan penting dalam mempengaruhi corak pemerintahan pada era sebelum kedatangan Barat. Agama Hindu, Buddha dan Islam mendominasi rantau Nusantara dan Borneo pada zaman ini.

Kedatangan pihak imperialis ke rantau Asia, yang bermotifkan 3G, iaitu Gold, Gospel dan Glory $^{l}$ yang popular pada Zaman Penemuan, tidak mengecualikan rantau Asia Tenggara. Fokus kepada kuasa British sebagai pihak imperialis, British telah menjajah Tanah Melayu, Sabah dan Sarawak. Campur tangan British dalam hal ehwal politik dan ekonomi kawasan dan negeri-negeri di Borneo ini menyumbang kepada kejatuhan negeri dan kawasan di Borneo tersebut ke tangan British. Misalnya, campur tangan James Brooke dalam menyelesaikan pemberontakan dalaman terhadap pembesar di Sarawak telah menyebarkan pengaruh British di Sarawak.

Melihat secara langsung di salah satu kawasan lingkungan Borneo, iaitu Sabah yang dahulunya dikenali sebagai Borneo Utara, catatan rekod awal politik di Sabah memperlihatkan penguasaan oleh Kesultanan Brunei semenjak abad ke-16. Menjelang abad ke-19, pemerintahan di Sabah terbahagi kepada dua kawasan lingkungan pengaruh iaitu, kawasan Pantai Barat Sabah di bawah zon pentadbiran Kesultanan Brunei manakala kawasan pantai Timur oleh Kesultanan Sulu. (Lokin, 2007:1-2) Wilayah di Pantai Barat Sabah meliputi seluruh wilayah dari Sungai Sulaman hingga Teluk Marudu, dan ke Sungai Paitan. Antara wilayah di Pantai Barat yang berkepentingan kepada British dari aspek politik khususnya, adalah Labuan. (Hall, 2007)

Kedatangan Jepun ke Asia Tenggara dan seterusnya menceroboh dominasi politik Barat di rantau Asia sekitar tahun 1941 sehingga 1945 telah menyaksikan bagaimana sistem politik wilayah dan kawasan naungan British mengalami evolusi, walaupun Jepun hanya menguasai lingkungan Asia dalam tempoh yang singkat. Labuan menjadi tempat pertama pencerobohan oleh Jepun untuk menguasai Borneo Utara, di mana penaklukan terhadap Labuan telah dilakukan pada 1 Januari 1942. (Ooi, 2011)

Perubahan dan perkembangan politik yang dilaksanakan oleh pihak pemerintah menjadi satu gaya atau trend yang berkepentingan, tidak kira lah pada zaman lampau mahupun kontemporari, dalam melihat perubahan dunia secara keseluruhan. Faktor-faktor penguasaan wilayah-wilayah di Asia oleh para imperialis Barat seperti Portugis, Sepanyol, British, Belanda, Perancis dan Jepun didorong oleh polisi dan ideologi yang dibentuk dalam sistem politik negara. Inilah yang mendorong penjelajahan, penerokaan, pencerobohan, penguasaan, imperialisme dan peperangan berlaku untuk tujuan mencapai tujuan politik negara-negara penjajah ini. Kemudiannya, pengaplikasian politik dan pentadbiran dilakukan di kawasan dan wilayah jajahan yang akhirnya mengubah sistem politik asal tempatan (tradisional) sama ada secara langsung atau tidak langsung. Perkembangan dan pembangunan politik di kawasan-kawasan yang telah dijajah di Asia Tenggara dan Borneo selalunya sinonim dengan peranan para penjajah. Namun begitu, penduduk tempatan dan peribumi secara realitinya turut menyumbang kepada perkembangan politik di kawasan masing-masing. Berikutan kesedaran kepada realiti dan hakikat kepentingan penduduk tempatan dan peribumi dalam perkembangan dan perubahan politik dan pentadbiran yang berubah arus ini, usaha demi usaha dilakukan oleh 
para pengkaji dalam mengupas peranan golongan ini secara terperinci di kawasan-kawasan yang ada dalam lingkungan Borneo, Malaysia, Sarawak dan Sabah. Beberapa pandangan daripada ahli akademik dan pengkaji berikut dapat menjelaskan kepentingan kajian yang bertemakan 'penglibatan peribumi dalam pentadbiran dan politik' sama ada secara langsung atau tidak langsung.

Dalam memahami kewujudan trend atau tema kajian terhadap peribumi secara umum, pernyataan ahli sosiologi iaitu J. M. Gullick dalam 'Indigenous Political System of Western Malaya' yang diterbitkan pada tahun 1988, boleh dijadikan sebagai contoh yang relevan. Beliau ada mengemukakan berkaitan dengan kerancakan atau perhatian yang diberikan oleh sarjana Barat mahupun tempatan dalam menghasilkan penulisan berkenaan dengan kerajaan-kerajaan Melayu dan masyarakat Melayu (peribumi), serta kebudayaan mereka. Walaupun pernyataan tersebut tidak menyentuh berkenaan dengan kajian terhadap 'peribumi atau penduduk tempatannya' secara spesifik, namun pernyataan ini agak jelas menunjukkan pengaruh 'Melayu', iaitu sesuatu bangsa peribumi, terhadap perkembangan tema penulisan bercorak sebegini secara tidak langsung, seperti yang berikut:

"Since this book appeared, other authors have published studies of other Malay states, drawing to a greater or less extent on Malay as well as European sources (Brown 1970, Khoo Kay Kim 1972, Milner 1982, Roff 1974, Shaharil Talib 1984, Sharom Ahmat 1984, Sullivan 1982, Sutherland 1978, Trocki 1979). The legal and Islamic aspects of Malay culture in an historical context have been examined by Hooker (1970, 1972, 1976, 1983 and 1984) and his joint authors. A number of Malay state histories, previously almost unknown or inaccessible, have been published (Muhammad Hassan 1968, Wan Mohammad Amin 1966 and Raja Haji Ali 1932/1982). Malay writers of the present day also have contributed to the growing corpus of academic work. These studies have incidently published material drawn from state archives of formerly independent Malay governments in Johor, Kedah, Terengganu among others. Most writers have put forward general hypotheses have done so on the basis of a study of a particular Malay state. Opinions may differ but in my view Windstedt's attempt to construct a general 'Cultural History' (Windstedt 1947) illustrated the inherent weakness of that very wide approach. He had after all completed four major histories of individual Malay states (Windstedt 1932, 1934a and 1934b, and Windstedt and Wilkinson 1934) and written a large number of other books and articles on these themes before attempting a synthesis of Malay culture."(Gullick, 1988:viii)

Fokus terus kepada kajian di Sabah, misalnya, menurut Dahlan (1985), dalam 'Kajian Etnografi Sabah Jilid 9, (1985)' oleh Osman (1985), penerbitan buku berkaitan dengan pentadbiran peribumi di Sabah sebelum Perang Dunia Kedua dapat membantu proses pemupukan kesedaran Sejarah tentang kebangkitan suatu bangsa yang pernah mengalami tahap penjajahan. Kewujudan sistem pentadbiran ini tentunya menandakan suatu peringkat pembentukan dasar kolonial untuk menyerap lambang-lambang tradisi tempatan yang berwibawa ke dalam regim kolonial. Penilaian tentang sistem ini dari segi memahami keadaan peribumi hari ini dirasakan amat perlu dan wajar. Kajian terhadap peribumi juga boleh menzahirkan sikap dan penilaian pegawai penjajah terhadap pimpinan peribumi tempatan. Hakikat ini penting diteliti kerana di situlah terungkapnya penilaian kolonial pada ketika itu terhadap suatu bangsa penjajah dan sikap kolonial terhadap dasar pemerintahan secara tidak langsung. Tambahan beliau lagi, kajian juga penting kerana dapat menginsafkan kita tentang nilai diri kita sebagai suatu bangsa yang pernah terjajah.

Pengkaji utama berkaitan dengan peranan dan penglibatan peribumi dalam pentadbiran dan politik di Sabah iaitu, Sabihah Osman turut menghuraikan beberapa kepentingan golongan peribumi ini dalam penulisan beliau, dan peranan golongan ini jelas menunjukkan mengapa relevannya suatu 
pengkajian terhadap mereka wajar dilaksanakan. Merujuk kepada hasil penulisan beliau yang bertajuk 'D. J. Jardine and Native Administration in Sabah 1934-1937', beliau menyatakan peranan golongan peribumi dalam menjamin kestabilan pentadbiran dan politik penjajah (termasuk dari segi kewangan), terutama sekali di bahagian pedalaman. Tanpa campur tangan dan kerjasama daripada ketua-ketua peribumi, golongan penjajah sesungguhnya tidak akan mampu menjamin kestabilan pentadbiran dan seterusnya politik di sesebuah kawasan. Ketua peribumi mempunyai kepentingan suara dalam mempengaruhi pentadbiran sesebuah kawasan. Peranan peribumi secara tidak langsung yang dapat dikenalpasti pula adalah apabila sistem perundangan peribumi digunapakai oleh pihak kolonial dalam pentadbiran. Contohnya, Sistem Undang-Undang Peribumi yang diambil dari sistem Perundangan Kesultanan Sulu telah digunakan oleh William Pryer dalam pentadbirannya di Sandakan. (Osman, 1982)

Pengkaji institusi peribumi di Sabah dan penulis Hamzah (t.t.) juga menzahirkan pandangan beliau berkenaan dengan kepentingan penglibatan peribumi yang spesifik kepada peribumi Islam, seperti berikut:

"The British must have learned form their earlier administration in Malaya, which they did successfully by not interfering in the religious and cultural affair of the Malays. They knew that the local Malayo-Muslims, besides being aware of the fact that once they held political power in those area in Sabah, like their Malayan counterparts, were also highly sensitive to matters pertaining to Islam. As for the non-Muslim natives, it was easier for the British to deal with them since they lacked political consciousness. Thus, in order to procure Muslim support, the British retained in their administration the important part of the traditional Bruneian System of Government. "(Hamzah, t.t.:181)

Lokin (2007) turut menyatakan kepentingan kajian terhadap pensejarahan peribumi dalam hasil kajian beliau yang bertajuk 'Perubahan Sosioekonomi dan Pentadbiran Masyarakat Peribumi Sabah (1881-1963)'. Menurut beliau, Sabah merupakan negeri yang mempunyai masyarakat yang terdiri daripada pelbagai kelompok suku peribumi. Dalam mengkaji aspek-aspek mengenai perubahan sosioekonomi dan pentadbiran di Sabah, tidak dapat tidak dipersoalkan identiti kelompok yang dikelaskan sebagai 'peribumi' di Sabah. Melalui pandangan beliau ini, jelas bahawa dalam memahami suatu pengkajian berkenaan perubahan dalam sosioekonomi mahupun pentadbiran, pentingnya juga penjelasan berkenaan dengan 'peribumi' dilakukan berikutan "masyarakat asal" sesuatu kawasan tersebut memberikan pengaruh besar terhadap perubahan yang berlaku di situ.

Antara contoh-contoh kajian peribumi dalam pentadbiran dan politik di Malaysia secara langsung dan tidak langsung, yang menjadi rujukan asas dan panduan kepada kajian sejarah peribumi di Labuan ini adalah seperti oleh Gullick (1988), 'The Indigenous Political System of Western Malaya', Aini dan Mersat (2008), 'Bumiputera Islam dalam Politik Sarawak (1963-2007)', Osman (1987), 'Malay-Muslim Political Participation in Sarawak: 1952-1987', Said (1985), 'Malay Politics in Sarawak (1946-1966)', Islam (2005), 'The Politics of Islamic Identity in Southeast Asia', Hooker dan Othman (2003), 'Malaysia: Islam, Society and Politics: essays in honour of Clive S. Kessler', Hussin (t.t.), 'Guru-Guru Melayu: Peranan dan perjuangan pada Zaman Penjajahan', Rogers (1993), 'Local Politics in Rural Malaysia: Patterns of Change in Sungai Raya', dan juga oleh Munip (1984) yang bertajuk 'Bandar Maharani dan Daerah Muar 1884-1920: Peribumi dan Permodenan'.

Beralih terus kepada bahagian Malaysia Timur, di sebelah Utara iaitu negeri Sabah, turut agak banyak kajian yang menumpukan penglibatan peribumi dalam pentadbiran dan politik secara langsung dan tidak langsung seperti oleh Osman (1982), 'D. J. Jardine and Native Administration in Sabah 19341937', Phelan (2003), 'Native Law in Sabah: Its Administrator: Headmen and Native Chiefs', Hamzah (t.t.), 'Development of the Native Chief Institution of Sabah', Tarsat (2007), 'Institusi Pentadbiran Pribumi: Satu Kajian Mengenai Ketua Anak Negeri di Sabah, 1946-1990', Osman (1985), 'Pentadbiran 
Peribumi Sabah 1881-1941', Lokin (2007), 'Perubahan Sosioekonomi dan Pentadbiran: Masyarakat Peribumi Sabah (1881-1963)', Sullivan dan Leong (1981) ,'Commemorative History of Sabah 18811981', Molukan (1987), 'District Administration in Sabah Pre-Independence: Kertas Kerja seminar', Magerat (1974), 'The Politics of Belonging: Political Change in Sabah and Sarawak', Robert (1976), 'Native Courts and the Institution of Native Chiefs in Sabah', Osman (1989), 'The Role of Governor D. J. Jardine in Improving the Welfare of the Indigenous People of Sabah 1934-37. Journal of Southeast Asian Studies', Kitingan dan William (1990), 'Development Of Administration System In Sabah Since Independence', Buyong (1981), 'Perjuangan Peribumi Menentang Penjajahan di Sabah: Protes Terhadap Nilai Barat: Kertas Kerja Seminar', Luping (1985), 'The Kadazan and Sabah Politics', Labansin (t.t.), 'Perkembangan Pasukan Polis di Sabah 1881-1942', Luping (1994), 'Sabah's Dilemma: The Political History of Sabah (1960-1994)', Yusin (2009), 'Sejarah Penyertaan Pemimpin Islam Di Dalam Parti UPKO dan PBS (1961-1994)', Ongkili (t.t.), 'Kadazan Tribal Leadership and Ethnic Consciousness in Pre-Colonial Sabah, Sabah Society Journal' dan juga Aziz (2005), 'Parti Politik USNO dan BERJAYA di Sabah 1961-1996'.

Kajian-kajian tersebut menjadi panduan yang penting dalam menilai relevannya kajian terhadap peribumi beragama Islam (majoriti dan penduduk asal) dalam konteks Labuan ini dilakukan.

\section{Latar Belakang Kajian terhadap Labuan}

Beberapa kajian terhadap penglibatan peribumi mahupun pentadbiran dan politik secara spesifik di daerah-daerah di Sabah juga sudah dilakukan. Contohnya, oleh Laindri (t.t.), 'Penglibatan Masyarakat Bugis dalam Politik dan Pentadbiran di Tawau, Sabah 1963-2012', Norbert (2010), 'Institusi Pentadbiran Peribumi Daerah Tambunan, 1963-2006', Mentua (2011), 'Tokoh Peribumi Daerah Kota Belud, Sabah: OKK Datuk Golkhan bin Hasbullah (1947-2009)', dan Jainal (2012), 'Sejarah Pentadbiran Daerah Kecil Membakut dari Tahun 1977 sehingga 2012'. Penglibatan peribumi secara khusus di Sandakan, Kota Kinabalu (dahulunya Jesselton), Semporna dan lain-lain daerah di Sabah sememangnya sudah banyak dijelaskan dan dihuraikan dalam penulisan-penulisan yang menumpukan kajian terhadap pentadbiran dan politik Sabah. Labuan dipilih sebagai kawasan kajian untuk mendukung tema kajian berkenaan dengan 'peribumi', dan 'politik', yang dihubungkaitkan menjadi 'penglibatan peribumi Islam dalam politik', berikutan isu kelompangannya dari segi Sejarah. Krisis kelompangan sejarah di Labuan ini juga menjadikan pengetahuan berkenaan dengan penglibatan peribumi dalam politik di Labuan masih tidak jelas. Hal ini juga dilihatnya tidak adil kerana, sedangkan daerah-daerah kecil lain di Sabah sekalipun, sudah mempunyai kupasan berkenaan kajian terhadap peribumi dan politiknya. Adakah perkara ini wajar berlaku, lebih-lebih lagi status Labuan yang diiktiraf sebagai 'Wilayah Persekutuan', yang pada dasarnya diibaratkan setaraf dengan Wilayah Persekutuan Kuala Lumpur?

Sememangnya wujud beberapa penulisan terdahulu mahupun dalam beberapa dekad awal berkenaan Labuan seperti oleh Hall (2007), 'Labuan Story: Memoirs of A Small Island Near The Coast of North Borneo', Evans (2007), 'The History of Labuan (Victoria Island)', Leong (t.t.), 'Labuan: Past, Present and Future', Yap (1958), 'The Founding of Labuan', Foong (1998), 'A General Overview on Labuan, Malaysia's International Offshore Financial Centre' dan juga oleh Aziz (2001) yang bertajuk 'Labuan 1846-1963: Dari Pangkalan Semulajadi ke Pelabuhan Terancang', serta banyak lagi kajian yang secara kasarnya membincangkan berkenaan dengan pensejarahan di Labuan. Namun, pelbagai kajian ini masih lagi tidak lengkap berikutan terlalu menumpukan aspek ekonomi atau peranan Labuan sebagai sebuah pelabuhan, selain juga hanya dijadikan sebagai 'sejarah pinggiran' bagi melengkapi pensejarahan yang lain. Penghuraian adalah tidak lebih daripada itu. Antara kajian yang hanya menyentuh pensejarahan Labuan sebagai 'sejarah pinggiran' adalah seperti kajian-kajian oleh Albaghdady (2003), Jilin (2005), Chindalia (2006), Ashari (1999), Mat Zain (1998), Ibrahim (1998), Mustaffa (1999), Rohia (1994), Jusoh (1999), Awang (1999), Padzil (1998), Yusin (2009), Md. Shah (1995), Yunos (1998), Ali, et al. (2000), Lapian (1996), Ahmad (1983), Irwin (1955), Jones (2007), Macfarlene (2005), Mohd. Ariff. (1995), Ooi (2011), Rutter (1922), Singh (1984), Treacher (1891), Warren (2007), Idris (2007), Ingleson (1971) dan Wong (1961). 
Adanya pula kajian berkaitan pentadbiran Labuan seperti Latihan Ilmiah bertajuk 'Labuan: 1846-1963: Perkembangan Dalam Pentadbirannya' oleh Shaifoodin (2010) sesungguhnya hanya mencerminkan gaya pentadbiran penjajah British secara umum dan tidak dilakukan secara mendalam. Sesungguhnya turut dihasilkan kajian berkenaan dengan pentadbiran British di Pulau Labuan oleh Danin (1991). Namun, kajian tersebut terhad kepada tahun 1846 sehingga 1890 sahaja. Selain itu, turut dilakukan kajian dari aspek politik, ekonomi dan sosial Labuan oleh para pengkaji dan sejarawan dari Universiti Malaya yang diketuai oleh Professor Dr. D. S. Ranjit Singh bersama ahli-ahli sejarawan yang lain seperti Professor Dr. Abdullah Zakaria Ghazali, Prof. Madya Dr. Danny Wong Tze Ken dan Dr. Ho Hui Ling, pada tahun 2004 sehingga tahun 2006, bagi mendokumentasikan Sejarah Labuan secara menyeluruh. Namun begitu, kajian yang dijalankan adalah masih lagi terhad kerana hanya melibatkan kajian secara umum seperti kajian-kajian sebelumnya, dalam bidang politik, sosial dan ekonomi yang diterbitkan dalam bentuk laporan (report) sebanyak empat bahagian, untuk Perbadanan Labuan. Tambahan lagi, kajian tersebut dilihatnya juga lebih cenderung menghuraikan dasar-dasar pentadbiran dan politik pihak penjajah British sahaja, tanpa memperincikan serta mengupas penglibatan penduduk tempatan secara mendalam. Tiada analisis yang terperinci dilakukan terhadap penduduk peribuminya. Kajian kontemporari yang spesifik, yang merungkaikan persoalan "mengapa Labuan diserahkan kepada Wilayah Persekutuan?" juga telah dilaksanakan oleh Leeudin (1984), namun hanya menfokuskan kepada tujuan yang sempit, iaitu untuk menjawab persoalan yang diketengahkan dari aspek kepentingan kepada kerajaan dan negara secara keseluruhan. Kajian tersebut juga mempunyai agenda tertentu iaitu untuk menghentikan spekulasi dan kontroversi tidak berasas masyarakat terhadap isu penyerahan Pulau Labuan.

Selain daripada keperluan untuk mengisi kelompangan sejarah Labuan, kajian Labuan juga dilakukan akibat kesedaran untuk mencari sudut "kekuatan" Labuan dalam bidang kajian dan sumber ilmu pengetahuan. Sebilangan besar kajian, khususnya dalam bidang sejarah, yang dilakukan sebelum ini hanya menjelaskan, menghuraikan dan menyatakan "kegagalan" pulau Labuan dalam mencapai objektif politik dan sosioekonomi semenjak zaman Brisith sehingga ia dijadikan sebagai Wilayah Persekutuan Labuan. Pelbagai isu berkenaan dengan pembangunan Labuan seringkali diketengahkan berdasarkan "kegagalan" ini. Segelintir daripada kajian-kajian tersebut juga telah dinyatakan pada halaman-halaman sebelumnya.

Konteks kajian berkenaan penglibatan peribumi (Islam) di Labuan ini dilihatnya membantu dalam menonjolkan "kejayaan" dalam pensejarahan yang berkaitan dengan perkembangan politik penduduk tempatan, seiring dengan daerah-daerah lain di Borneo Utara mahupun Sarawak dan Tanah Melayu, walaupun latar belakang pentadbiran dan politik Labuan yang kerapkali mengalami perubahan memberikan gambaran 'ketidakstabilan politik yang berpanjangan' di Labuan. (Hall, 2007)

Justeru, permasalahan kajian telah dibentuk berdasarkan tema tersebut iaitu, untuk mengenalpasti aktiviti-aktiviti peribumi Islam dalam politik di Labuan zaman penjajahan British 19461963 dan meneliti sama ada British memberikan peluang yang sewajarnya kepada peribumi Islam untuk terlibat dalam politik di Labuan atau sebaliknya, melalui reaksi British terhadap penglibatan ini. Permasalahan kajian ini adalah bersesuaian dengan objektif kajian iaitu untuk menghuraikan bentuk penglibatan peribumi Islam dalam politik di Labuan tahun 1946-1963 dan seterusnya menganalisis peranan serta dasar politik British terhadap peribumi Islam di Labuan. Ketiga-tiga objektif juga membantu dalam menjelaskan kedudukan peribumi Islam dalam politik di Labuan.

\section{Pendekatan Kajian}

Pendekatan pertama dalam melaksanakan kajian adalah kajian perpustakaan konvensional dan perpustakaan atas talian (Online Library). Melalui pendekatan ini, sumber primer seperti Colonial Office File (C.O.), Foreign Office File (F.O.C.), Secretariat File dan surat-surat khabar lama, laporan tahunan British dalam tempoh 1846 sehingga 1960-an (Annual Report State of North Borneo British) dan fail-fail rasmi kerajaan British Borneo lain yang berkaitan, serta surat-surat individu yang terdapat 
di Perpustakaan Negeri Sabah dan Arkib Negeri Sabah dapat diperolehi. (Aziz, et al, 2014:48-62) Sumber primer spesifik berkenaan Labuan juga diperolehi di Perpustakaan Perbadanan Labuan dan Muzium Wilayah Persekutuan Labuan. Minit-minit mesyuarat persatuan-persatuan yang terlibat juga merupakan sumber primer yang dirujuk dalam pelaksanaan kajian. Manakala, sumber sekunder diperolehi dalam bentuk buku, artikel dalam jurnal dan Gazzete (surat khabar) di perpustakaanperpustakaan yang berkaitan. Sebahagian daripada bahan-bahan ini telah didigitalkan dan dapat diakses melalui pangkalan data Perpustakaan Universiti Malaysia Sabah, Perpustakaan Negeri Sabah, Arkib Negeri Sabah, Arkib Negara Brunei dan sebagainya.

Pendekatan kedua dalam pengumpulan data adalah melalui kajian lapangan. Kajian lapangan dalam mengumpulkan sumber lisan diperolehi melalui kaedah temu bual mendalam (in-depth interviews). Penduduk atau tokoh-tokoh veteran, atau yang berkaitan di Labuan yang mempunyai pengalaman khas dalam pentadbiran dan politik era penguasaan penjajah Inggeris di Labuan selepas Perang Dunia Kedua telah dititikberatkan, selain daripada para pensyarah Sejarah yang mengetahui Sejarah Labuan. Dalam menganalisis data dan sumber yang telah dikumpulkan pula, kaedah kritikan dalaman, iaitu menganalisis keaslian fakta berdasarkan perbandingan antara sumber dilakukan. Kaedah kritikan luaran turut diaplikasikan. Kajian berusaha untuk tidak cenderung ke arah mana-mana perspektif yang boleh menimbulkan sentimen European-centric atau Malaysian-centric dalam penulisan. (Aziz, et al, 2014:55-56) Cross-checked (semakan) juga dilakukan terhadap maklumat daripada temu bual dengan sumber-sumber primer yang berkaitan, untuk mendapatkan fakta yang sahih.

\section{KONSEP PERIBUMI (ISLAM)}

Istilah 'peribumi' ${ }^{2}$ dalam konteks umum diistilahkan sebagai masyarakat asli atau tempatan. Oleh yang demikian, peribumi adalah penduduk asal di sesebuah kawasan tersebut. Pada asasnya juga, peribumi merujuk kepada penduduk tempatan sebelum kedatangan penjajah Barat. Jika pengertian peribumi menggunakan garis sejarah yang sedemikian, maka orang Melayu adalah peribumi bagi seluruh Borneo-Nusantara. Hal ini kerana, bagi rantau Borneo-Nusantara, Melayu adalah penduduk yang sudah wujud di rantau ini sebelum kedatangan Sepanyol, akibat keruntuhan Islam Kardova pada abad ke-13 dahulu. Istilah peribumi itu sendiri juga terbit daripada Bahasa Melayu yang pada asasnya merupakan Bahasa Sanskrit.

Labuan tidak mempunyai penghuni yang tetap pada peringkat awal. Hanya wujud beberapa pondok rehat nelayan yang singgah untuk menangkap ikan dan hasil laut yang lain, pada peringkat awal British menguasai pulau tersebut. Kemudian, populasi penduduk telah bertambah akibat daripada pelaksanaan dasar British yang menggalakkan perdagangan dan menjadikan Labuan pelabuhan bebas cukai, yang akhirnya menyebabkan pembukaan petempatan kekal dilakukan. Pembentukan masyarakat atau sistem sosial yang jelas di Labuan bermula menjelang tahun 1846. (Hall, 2007)

Meskipun wujud segelintir catatan dan laporan tahunan British (British Annual Report) yang menyatakan pernah wujud perjanjian perdagangan di Labuan serta wujudnya petempatan awal oleh kuasa asing seperti Portugis ${ }^{3}$ seawal abad ke-16, dan oleh British yang dipelopori oleh orang-orang dari Syarikat Hindia Timur Inggeris sekitar tahun 1775, namun, tinggalan dan bukti berkenaan wujudnya petempatan tersebut sukar didapati, atau langsung sama sekali tidak dijelaskan secara terperinci. Turut wujud catatan bertulis British dan sarjana tempatan yang telah mengesahkan bahawa tidak wujud petempatan kekal di Labuan sebelum 1846, namun, menurut sumber daripada Tarsilah Brunei ${ }^{4}$, dikatakan telah ada penduduk Brunei yang telah tinggal menetap di Labuan, menjadi nelayan atau bercucuk tanam secara turun-temurun. Dikatakan juga, semasa pertelingkahan taktha Kerajaan Brunei berlaku, Pulau Labuan pernah menjadi tempat pengasingan diri Pengiran Muda Besar Abdullah Ibnu Abdul Jalilul Akhbar dan keluarga beliau. Malah, semasa zaman pemerintahan Sultan Muhyiddin dalam tahun 1685, utusan Sepanyol daripada Manila yang hendak menghadap baginda ditempatkan selama enam bulan di Pulau Labuan sementara menanti persiapan penerimaan menghadap tersebut. Sumber lain yang diperolehi daripada temu bual terhadap ketua kampung Patau-Patau I, Encik Osman bin Matusin pula menyatakan telah wujud perkampungan di Labuan seawal tahun 1820-an lagi, iaitu 
Kampung Patau-Patau I di Labuan. Walaubagaimanapun, tiada bukti secara kukuh berkenaan kenyataan-kenyataan ini. Maka, konklusinya, sememangnya tiada petempatan kekal yang berjaya dibuka oleh sesiapapun sehinggalah pertapakan British secara rasmi pada tahun 1846.

Pada peringkat awal ini (selepas 1846), masyarakat Kedayan yang rata-ratanya menganuti agama Islam merupakan kumpulan manusia yang terawal membina petempatan kekal di Labuan. Dipercayai bahawa, orang-orang Kedayan ini merupakan golongan hamba yang berasal dari Brunei, yang telah melarikan diri ke Labuan demi mendapatkan perlindungan daripada British. (Hall, 2007) Pembukaan petempatan kekal oleh mereka menjadi satu sejarah terawal kependudukan tempatan di Labuan. (Sidek, 2007:21-24) Selain itu, kumpulan masyarakat Kedayan yang turut membuka petempatan awal di Labuan adalah orang-orang merdeka yang ingin mencari tanah baru untuk diusahakan, dan seterusnya dijadikan hak milik bergenerasi. Masyarakat Kedayan terkenal dengan kecekapan mereka dalam bidang pertanian, terutamanya dalam penanaman padi. Mereka juga sinonim dengan ekonomi perladangan, bekerja sebagai penoreh getah dan terlibat dalam aktiviti penangkapan ikan sebagai nelayan. (Hall, 2007:6)

Walaupun terdapat banyak perdebatan berkenaan dengan siapa sebenarnya penduduk asal dan tetap Labuan, seperti yang telah dikemukakan, namun, berikutan tiada bukti yang jelas berkenaan dengan kependudukan yang tetap di Labuan sebelum penguasaan British, etnik (Kedayan) yang terawal mempelopori dan tinggal di Labuan secara "nomad' "dianggap" sebagai penduduk tetap Labuan menurut Danin (1991), seperti yang berikut:

"Penduduk asal Labuan ialah orang-orang Kedayan yang datang berhijrah dari Kerajaan Kesultanan Brunei. Mereka ini beragama Islam yang merupakan penduduk 'tetap' sejak zaman Kesultanan Brunei lagi. Pada masa pemerintahan kerajaan British, orang-orang Kedayan ini telah berhijrah ke Labuan untuk mengerjakan tanah-tanah yang terbiar. Sebahagian daripada mereka bekerja menjadi nelayan di sekitar pulau tersebut." (Danin, 1991:106)

Dalam membincangkan peranan dan kedudukan golongan masyarakat tempatan dalam arena politik di Labuan juga, istilah 'peribumi' dan bukannya 'Melayu' digunakan kerana meskipun fokus kajian adalah kepada dua etnik iaitu etnik Melayu Brunei dan Kedayan (etnik majoriti), berikutan sememangnya kedua-dua etnik adalah pada asasnya adalah beragama Islam, namun, turut wujud sebilangan kecil masyarakat Islam (minoriti) lainnya di Labuan yang bukan terdiri daripada salah satu etnik tersebut. Misalnya, Kadazandusun Muslim atau anak tempatan yang mempunyai darah kacukan orang Barat yang turut bertapak awal di Labuan. Mereka ini secara generalisasinya turut digelar 'peribumi Islam'. Kewujudan mereka sesungguhnya tidak boleh dilepas pandang dalam membincangkan berkenaan peranan peribumi Islam dalam pentadbiran dan politik di Labuan kerana merupakan golongan yang berada dalam kumpulan yang sama dalam kitaran masyarakat peribumi yang beragama Islam disebabkan mengamalkan cara hidup, budaya dan ajaran Islam yang sepunya. Peribumi Islam dari kawasan daerah-daerah lain di Sabah yang berkhidmat di Labuan dalam bidang pentadbiran dan politik juga turut dirangkumi dalam perbincangan berkenaan dengan konteks kajian Labuan ini.

\section{LATAR BELAKANG POLITIK UMUM DI LABUAN SEPINTAS LALU}

Labuan terletak pada bahagian pantai Barat-Laut negara Brunei Darussalam, iaitu pada kedudukan 40 batu dari sungai Brunei. Labuan yang mempunyai bentuk seakan-akan segi tiga ini mempunyai keluasan $92 \mathrm{~km}$ persegi yang merangkumi bentuk muka bumi rata dan beralun dengan titik tertinggi 100 meter di atas paras laut. Suhu harian Labuan adalah sekitar 70 sehingga 92 darjah Fahrenheit. Iklim Labuan dipengaruhi oleh angin monsun. Purata hujan tahunan adalah sebanyak 130 inci setahun. Puncak atau titik tertinggi Labuan adalah Bukit Kalam, yang berada 280 kaki dari paras laut. ${ }^{5}$ 
Labuan merupakan satu wilayah koloni yang unik berikutan mengalami perkembangan politik dan pentadbiran yang berbeza jika dibandingkan dengan wilayah koloni yang lain di Borneo, kerana satu-satunya pulau yang ditadbir oleh beberapa kuasa atau syarikat, walaupun masih lagi di bawah penguasaan British. Pihak Admiralty British (1846-1848) telah menerajui pentadbiran di Labuan selepas Kesultanan Brunei, dan diikuti dengan pihak British sendiri (1848-1889), Syarikat Berpiagam Borneo Utara (SBBU) (1890-1906), Negeri-Negeri Selat (NNS) (1906-1941) dan seterusnya pihak Jepun (1941-1948) sehinggalah Perang Dunia Kedua berakhir (Evans, et al., 2004). Pelbagai dasar dan transformasi serta pelan pembangunan yang berbeza-beza mengikut corak pemerintahan setiap kuasa yang mentadbir Labuan membawa kepada perkembangan politik dan pembangunan yang dilihatnya tidak berjaya menjadikan Labuan seperti yang diharapkan pada ketika itu. (Hall, 2007)

\section{DAPATAN KAJIAN}

\section{Penglibatan Komuniti Peribumi Islam Dalam Politik di Labuan}

Keadaan dan penglibatan komuniti peribumi Islam dalam politik di Labuan selepas Perang Dunia Kedua boleh dibahagikan kepada dua fasa iaitu fasa pertama, bermula tahun 1946 sehingga tahun 1961 dan fasa kedua dari tahun 1961 sehinggalah tahun 1963. Fasa-Fasa ini memperlihatkan penglibatan komuniti peribumi Islam dalam aktiviti berpersatuan, parti-parti politik, tuntutan kemerdekaan dan penubuhan Malaysia, serta penglibatan dalam pilihan raya umum tempatan.

Keadaan politik dan penglibatan komuniti peribumi Islam pada fasa yang pertama pada amnya dimotivasikan oleh kesedaran untuk mempertahankan hak-hak agama (Islam), etnik, budaya dan kepentingan kumpulan daripada penjajah British. Pelbagai persatuan dan pertubuhan seperti Parti Kebangsaan Melayu Labuan (PKML), Persatuan Melayu Labuan (PML), BARIP Labuan dan Angkatan Desa telah ditubuhkan demi tujuan yang telah dinyatakan tadi. Sebelum tahun 1961, peranan dan penglibatan peribumi beragama Islam dianggap penting. Mengapa penduduk peribumi yang beragama Islam dan bukannya yang beragama Kristian atau lain-lain? Hal ini kerana, kemunculan dan kewujudan persatuan-persatuan yang 'berorientasikan' politik sebelum tahun 1961 di Labuan adalah implikasi daripada kesedaran terhadap masalah keagamaan dan sosial orang-orang Islam. Oleh yang demikianlah, peranan golongan peribumi Islam adalah sangat penting berikutan merekalah yang menjadi penggerak dan peneraju kepada persatuan-persatuan berbaur politik sebelum tahun 1961 (Aziz, 2005). Persatuanpersatuan lain yang ditubuhkan oleh bukan peribumi Islam pada ketika itu tidak berorientasikan keagamaan melainkan lebih kepada kepentingan dalam perniagaan, keuntungan dan hak-hak mereka secara umum. ${ }^{6}$

Sememangnya ramai sarjana yang berpendapat bahawa tidak wujud lagi "gerakan berpolitik" di Sabah (mahupun di Labuan) seperti yang dinyatakan oleh Ho (2003:61) ...."Selanjutnya, pada tahun 1940-an, beberapa buah lagi persatuan Islam telah ditubuhkan di Sabah. Antaranya, Persatuan barisan Pemuda (BARIP), Parti Kebangsaan Melayu (PKM) dan Khairat Jumaat Muslimin (KJM). Seterusnya, pada tahun 1950-an, Persatuan Ikhwan Sabah, Persatuan Islam Putatan (PIP) dan Persatuan Islam Sabah ditubuhkan dengan tujuan secara umumnya untuk menyatukan umat Islam dan mengajak mereka menghayati ajaran Islam berpandukan al-Quran dan Hadis. Pendek kata, pertubuhan yang wujud di Sabah sebelum tahun 1961 adalah bertujuan untuk menjaga kepentingan sosial, budaya dan agama komuniti yang diwakilinya. Pertubuhan-pertubuhan ini belum lagi memperjuangkan sebarang isu politik di Sabah. Pada ketika itu juga, pemimpin dan penduduk Sabah belum lagi memandang serius terhadap perkembangan politik di Sabah."

Sememangnya tidak wujud pertubuhan atau parti politik yang khusus dan rasmi memperjuangkan agenda berpolitik di Sabah sebelum tahun 1961. Namun, untuk menyatakan pertubuhan-pertubuhan yang wujud sebelum tahun 1961 belum memperjuangkan sebarang "isu politik" adalah tidak tepat. Kesedaran berpolitik dan gerakan berpolitik sudah wujud semenjak sebelum Perang Dunia Kedua lagi. Cuma, pergerakan ini diselitkan dengan perjuangan terhadap sosial, budaya dan agama di mana ianya tidak hanya terarah kepada gerakan politik semata-mata. Mungkin sebab itulah, 
gerakan politik di Sabah dilihatnya seakan-akan dilihat sebagai "tiada." Tambahan lagi, aktiviti dan perjuangan persatuan-persatuan tersebut sama ada di peringkat kampung atau daerah tetap akan melibatkan aspek politik secara tidak langsung berikutan tanpa "kuasa" (politik), di mana mereka akan berhubung dengan pihak pemerintah British atas apa sahaja urusan yang diperjuangkan, gerakan berpersatuan tidak akan berjalan dengan efisien. ${ }^{7}$

Dalam konteks Labuan juga, agama menjadi impetus penting kepada keterlibatan dalam politik disebabkan oleh beberapa pengaruh penting seperti pengaruh daripada Kesultanan Brunei, tuntutan dan ajaran Islam itu sendiri dan peranan tokoh agama di Labuan seperti imam Suhaili melalui dakwah Islamiyah (Aziz, 2005). Pengaruh agama Islam bukan hanya penting dalam mencorakkan perkembangan gerakan berpolitik di Labuan malahan juga turut penting dalam perkembangan politik di seluruh Sabah seperti dalam kenyataan berikut:

"Diantara pertubuhan yang wujud di Sabah sebelum 1961, pertubuhan bercorak keagamaan inilah yang berperanan dalam memberi kesedaran berpolitik kepada masyarakat. Ini kerana sewaktu melalui proses pengajian keagamaan mereka diserapkan dengan unsur "Jihad" iaitu semangat untuk melawan penjajah. Manakala kegiatan politik melalui badan kebudayaan begitu terhad kerana ianya bercampur baur antara aktiviti kebudayaan serta semangat kesedaran. Dapatlah dirumuskan, bahawa kesedaran berpolitik di kalangan masyarakat bumiputera Sabah telah wujud sebelum Perang Dunia Pertama lagi. Walau bagaimanapun selepas Perang Dunia Kedua, semangat kesedaran lebih terserlah setelah muncul dua pertubuhan politik dari kalangan masyarakat bumiputera Islam iaitu BARIP dan PKML.”(Aziz, 2005:52)

Maklumat daripada sumber-sumber lisan, khususnya daripada responden yang ditemubual di Labuan juga rata-rata bersetuju dan mengemukakan pendapat berdasarkan pengalaman mereka bahawa agama Islam memainkan peranan penting dalam mencetuskan penglibatan dalam gerakan berpolitik, yang dimulakan dengan keterlibatan dalam aktiviti persatuan dan organisasi pada era selepas Perang Dunia Kedua. Persatuan-persatuan yang aktif di Labuan menurut sumber lisan yang didapati adalah PKML, PML, BARIP dan Angkatan Desa. PKML, PML dan BARIP merupakan persatuan-persatuan yang mewakili golongan peribumi Islam di kawasan bandar dan kebanyakkannya bekerja sebagai kakitangan kerajaan dan guru. Manakala, Angkatan Desa pula diwakili oleh peribumi Islam di kawasan kampung-kampung yang bekerja sebagai petani dan nelayan. ${ }^{8}$

Manakala, kegiatan berpolitik persatuan dan seterusnya kewujudan parti-parti politik baru selepas tahun 1960-an adalah dipengaruhi oleh cadangan gagasan Malaysia. Persatuan-persatuan yang masih aktif di Labuan pada fasa kedua ini adalah Parti Kebangsaan Melayu Labuan (PKML), Persatuan Melayu Labuan (PML), BARIP Labuan dan Angkatan Desa. Di samping aktif dalam menentang sebarang ketidakadilan terhadap ahli-ahli mereka sama ada dalam bidang pekerjaan, kebudayaan, agama, hak ekonomi dan sebagainya, mereka turut memperjuangkan agenda politik baru sesudah gagasan Malaysia diumumkan. Kemunculan parti-parti politik seperti USNO, UNKO dan BUNAP cawangan Labuan dalam tahun 1961 merancakkan lagi perkembangan aktiviti berpersatuan dan parti politik di Labuan. (Singh, et al., t.t.)

Keadaan politik dan penglibatan masyarakat peribumi Islam pada fasa yang pertama dan kedua di Labuan dapat dilihat seperti berikut:

\begin{tabular}{|l|l|}
\hline $\begin{array}{l}\text { Fasa Pertama: Sebelum Gagasan Malaysia } \\
\text { Diwarwarkan }\end{array}$ & $\begin{array}{l}\text { Fasa Kedua: Selepas Gagasan Malaysia } \\
\text { Diumumkan }\end{array}$ \\
\hline $\begin{array}{l}\text { Dimotivasikan oleh agama Islam. Reaksi dan } \\
\text { tindak balas adalah terhadap penjajah British. }\end{array}$ & $\begin{array}{l}\text { Dimotivasikan oleh agenda politik iaitu } \\
\text { kemerdekaan Labuan dan hak-hak politik }\end{array}$ \\
\hline
\end{tabular}


Peranan masyarakat peribumi Islam di Labuan pada fasa kedua khususnya dalam tuntutan kemerdekaan dan penubuhan Malaysia boleh dilihat daripada jadual berikut:

Jadual 1: Perwakilan di Labuan kepada Suruhanjaya Cobbold

\begin{tabular}{|c|c|c|c|}
\hline Nama & $\begin{array}{l}\text { Wakil daripada: } \\
\text { Individu/Persatu } \\
\text { an/Kaum }\end{array}$ & $\begin{array}{l}\text { Reaksi terhadap } \\
\text { Penubuhan } \\
\text { Malaysia }\end{array}$ & Syarat yang Dikemukakan \\
\hline $\begin{array}{l}\text { 1. Lucas } \\
\text { Kong }\end{array}$ & Individu & Sokong & $\begin{array}{l}\text { 1. Sabah diberikan taraf yang } \\
\text { sama dengan negeri-negeri } \\
\text { Melayu yang lain. }{ }^{9} \\
\text { 2. } \\
\text { Labuan mempunyai kuasa } \\
\text { untuk keluar dari Malaysia dan } \\
\text { taraf Labuan sebagai } \\
\text { pelabuhan bebas dimasukkan } \\
\text { dalam Perlembagaan } \\
\text { Malaysia. }^{10}\end{array}$ \\
\hline $\begin{array}{l}\text { 2. Teo Soo } \\
\text { Tong }\end{array}$ & $\begin{array}{l}\text { Persatuan Cina } \\
\text { Labuan/ Chinese } \\
\text { Association dan } \\
\text { Tokong Cina }\end{array}$ & Sokong & $\begin{array}{l}\text { Sabah diberikan kerajaan sendiri } \\
\text { dahulu sebelum menyertai } \\
\text { Malaysia. }{ }^{11}\end{array}$ \\
\hline $\begin{array}{l}\text { 3. Tan } \\
\text { Chong Kim } \\
\text { dan empat } \\
\text { orang wakil }\end{array}$ & $\begin{array}{l}\text { Dewan } \\
\text { Perniagaan Cina } \\
\text { Labuan }\end{array}$ & Sokong & $\begin{array}{l}\text { Sabah dan Labuan diberikan } \\
\text { kerajaan sendiri dahulu sebelum } \\
\text { menyertai Malaysia. }^{12}\end{array}$ \\
\hline 4. & $\begin{array}{l}\text { The Labuan North } \\
\text { Borneo Chinese } \\
\text { Association }\end{array}$ & Sokong & $\begin{array}{l}\text { Melalui memorandum: } \\
\text { Labuan harus dikekalkan tarafnya } \\
\text { sebagai pelabuhan bebas selepas } \\
\text { Sabah menyertai Malaysia dan } \\
\text { dalam tempoh tujuh tahun, Sabah } \\
\text { mempunyai kuasa untuk menarik } \\
\text { diri dari Malaysia sekiranya } \\
\text { penduduk tidak berpuas hati } \\
\text { dengan perkembangan yang } \\
\text { berlaku di situ. }{ }^{13}\end{array}$ \\
\hline 5. & $\begin{array}{l}\text { Labuan Free Port } \\
\text { Guild }\end{array}$ & Sokong & $\begin{array}{l}\text { Melalui memorandum: } \\
\text { Mendesak supaya pelabuhan } \\
\text { Labuan dikekalkan sebagai } \\
\text { Pelabuhan Bebas setelah Malaysia } \\
\text { dibentuk, demi kepentingan } \\
\text { pembangunan ekonomi di Labuan } \\
\text { dan Sabah. }{ }^{14}\end{array}$ \\
\hline $\begin{array}{l}\text { 6. Fadzil } \\
\text { Asmad }\end{array}$ & $\begin{array}{l}\text { Individu/ ahli } \\
\text { Majlis } \\
\text { Perundangan } \\
\text { Labuan }\end{array}$ & Sokong & $\begin{array}{l}\text { 1. Sabah harus diberikan } \\
\text { kemerdekaan terlebih dahulu } \\
\text { sebelum menyertai Malaysia. }\end{array}$ \\
\hline
\end{tabular}




\begin{tabular}{|c|c|c|c|}
\hline & & & $\begin{array}{l}\text { 2. Sekiranya Malaysia menjadi } \\
\text { kenyataan, Labuan diletakkan } \\
\text { di bawah kekuasaan Sultan } \\
\text { Brunei. }^{15}\end{array}$ \\
\hline 7. & $\begin{array}{l}\text { Persatuan Melayu } \\
\text { Labuan/ The } \\
\text { Malay } \\
\text { Association, } \\
\text { Labuan }\end{array}$ & Sokong & $\begin{array}{l}\text { 1. Sabah harus diberikan } \\
\text { kemerdekaan terlebih dahulu } \\
\text { sebelum menyertai Malaysia. } \\
\text { 2. Menuntut penggunaan Bahasa } \\
\text { Melayu dan agama Islam } \\
\text { ditekankan dan penduduk } \\
\text { Sabah. } \\
\text { 3. menikmati hak yang sama dari } \\
\text { segi pendidikan, perkhidmatan } \\
\text { awam, ekonomi, pertanian dan } \\
\text { pembangunan lain. } 16\end{array}$ \\
\hline $\begin{array}{l}\text { 8. Daud bin } \\
\text { Usop dan } \\
\text { Abdul } \\
\text { Rahman bin } \\
\text { Yusof (2 } \\
\text { orang) }\end{array}$ & $\begin{array}{l}14 \text { buah kampung } \\
\text { (5000 penduduk } \\
\text { kampung di } \\
\text { Labuan) }\end{array}$ & Sokong & Tidak bersyarat. ${ }^{17}$ \\
\hline $\begin{array}{l}\text { 9. Lima } \\
\text { orang wakil } \\
\text { orang } \\
\text { Melayu }\end{array}$ & $\begin{array}{l}18 \text { buah kampung } \\
\text { ( } 2000 \text { penduduk } \\
\text { kampung di } \\
\text { Labuan) }\end{array}$ & $\begin{array}{l}\text { - } \\
\text { Menyuarakan } \\
\text { kebimbangan mereka } \\
\text { terhadap masa depan } \\
\text { Labuan dan Sabah } \\
\text { dalam Malaysia. } \\
\text { Meminta agar } \\
\text { Labuan dipulangkan } \\
\text { semula kepada } \\
\text { Kesultanan Brunei. }^{18}\end{array}$ & - \\
\hline $\begin{array}{l}\text { 10. Lima } \\
\text { orang } \\
\text { daripada } \\
\text { etnik } \\
\text { Kedayan dan } \\
\text { Melayu } \\
\text { Brunei }\end{array}$ & $\begin{array}{l}2000 \text { penduduk } \\
\text { dalam komuniti } \\
\text { Kedayan dan } \\
\text { Melayu Brunei. }\end{array}$ & $\begin{array}{l}\text { Tidak mnyokong } \\
\text { sepenuhnya (kurang } \\
\text { faham dengan idea } \\
\text { gagasan Malaysia) }\end{array}$ & $\begin{array}{l}\text { Mahukan Labuan diserahkan } \\
\text { kepada Brunei terlebih dahulu } \\
\text { sebelum Sabah menyertai } \\
\text { Malaysia. }{ }^{19}\end{array}$ \\
\hline $\begin{array}{l}\text { 11. F.E.P } \\
\text { Majanggil }\end{array}$ & $\begin{array}{l}\text { Pertubuhan } \\
\text { Kadazan Labuan }\end{array}$ & Sokong ${ }^{20}$ & - \\
\hline 12. & $\begin{array}{l}8000 \text { penduduk } \\
\text { Muslim }\end{array}$ & Sokong $^{21}$ & \\
\hline
\end{tabular}

Sumber: Dipetik dan diubahsuai daripada Ranjit Singh, et al., Labuan Report: Chapter 7: Labuan, 1946-1963, yang disimpan di Muzium Wilayah Persekutuan Labuan, (t.t.), hlm. 310-314.

Berdasarkan Jadual 1, 6 daripada 12 perwakilan ke Suruhanjaya Cobbold di Labuan adalah datangnya daripada orang-orang Melayu dan peribumi Islam yang mewakili orang perseorangan, persatuan, komuniti dan kampung. Kumpulan Melayu dan peribumi Islam Labuan ini mendominasi jumlah penduduk yang ada di Labuan dalam perwakilan ke Suruhanjaya Cobbold. Rata-rata daripada kalangan mereka ini mengemukakan syarat untuk mendapatkan kemerdekaan Labuan terlebih dahulu sebelum menyertai Malaysia. Penglibatan ini penting dalam pelaksanaan gagasan Malaysia yang akhirnya menjadi kenyataan. Tiada sumber atau fakta bertulis yang menjelaskan mengapa kumpulan Melayu dan peribumi Islam di Labuan berminat memberikan respon dalam jumlah yang ramai dan menggalakkan terhadap Suruhanjaya Cobbold. Namun, jika dianalisis, respon dan penglibatan mereka 
dalam jumlah yang banyak ini adalah disebabkan oleh pengaruh dan peranan pemimpin-pemimpin peribumi di peringkat kampung dan melalui persatuan-persatuan bermotivasikan politik dan agama Islam seperti PKML, PML, Angkatan Desa, PRL dan kelahiran parti politik USNO. (Rush, 1992)

Reaksi penduduk adalah berbeza, namun majoriti menyokong dengan syarat-syarat tertentu. Segelintir inginkan Labuan diberikan kemerdekaan terlebih dahulu, ada juga yang menginginkan agar Labuan dikembalikan kepada Brunei dan taraf Labuan sebagai pelabuhan bebas dikekalkan. Sememangnya wujud sedikit penentangan apabila pembentukan Malaysia diwarwarkan pada peringkat awal namun tidaklah berlaku secara serius. Labuan berada dalam zon selesa, tidak seperti wilayah atau daerah yang lain di Sabah. Penentangan pun hanya tertumpu kepada persatuan atau secara kumpulan atau terlibat dalam group activity, melalui penghantaran wakil, memorandum, tandatangan, syaratsyarat dan sebagainya. Tiada penentangan yang datang secara individu. Wujudnya cadangan untuk memisahkan Labuan daripada Sabah dan tidak puas hati dengan pentadbiran British di Labuan adalah berdasarkan kepada petikan laporan akhbar North Borneo News and Sabah Times, 1 September 1961, hlm. 1.

Pada tahun 1962, sebuah lagi jawatankuasa yang dikenali sebagai Inter-Government Comitee $(\text { IGC })^{22}$ dibentuk untuk merangka perlembagaan yang boleh menjamin hak dan kepentingan penduduk Borneo. Akhirnya, Sabah bersetuju menyertai Borneo. Dengan itu, Labuan yang merupakan sebahagian daripada Sabah turut menjadi sebahagian daripada Malaysia. Pada 16 September 1963, Sabah dan Labuan mencapai kemerdekaan melalui penyertaan dalam Persekutuan Malaysia. Dengan ini juga, nama Borneo Utara secara rasmi telah ditukarkan kepada Sabah. (Singh, et al., t.t)

Melihat kepada peranan golongan peribumi Islam dalam pilihan raya umum tempatan pula, Parti UNKO, USNO, BUNAP dan SAP telah muncul menjelang tahun 1962 dalam pada merealisasikan 'kerajaan sendiri' di Labuan. UNKO cawangan Labuan didaftarkan secara rasmi pada 10 Mei 1962 di bawah Regulation 14 of The Societies Regulations, 1962, Establishment of Branches of Local Societies, manakala USNO cawangan Labuan pula dibuka pada Mac 1962. Sabah Alliance Party (SAP) pula merupakan gabungan parti UNKO, USNO dan BUNAP. Untuk tujuan pilihan raya tersebut, Labuan dibahagikan kepada 8 ward (kawasan), yang merangkumi calon-calon daripada parti BUNAP, SAP dan calon bebas, seperti berikut (Singht, et al., t.t. : 305-306):

1. Victoria

2. Ramsay

3. Lapangan Terbang

4. Benuwa

5. Kubong

6. Layang-Layangan

7. Lajau

8. Lada

Berikut merupakan jadual senarai calon-calon yang bertanding dan jumlah undi yang diperolehi dalam pilihan raya tempatan bagi Labuan Town Board Area pada tahun 1962:

Jadual 2: Senarai Calon-Calon yang Bertanding dan Jumlah Undi yang Diperoleh Dalam Pilihan Raya Tempatan bagi Labuan Town Board Area Pada Tahun 1962:

\begin{tabular}{|l|l|l|l|l|}
\hline $\begin{array}{l}\text { Component/ } \\
\text { Area (Ward) }\end{array}$ & $\begin{array}{l}\text { Candidate and number } \\
\text { of votes }\end{array}$ & $\begin{array}{l}\text { Number of } \\
\text { Rejected } \\
\text { Ballot } \\
\text { Papers }\end{array}$ & $\begin{array}{l}\text { Number of } \\
\text { Names on } \\
\text { List of } \\
\text { Votes on } \\
\text { the Roll }\end{array}$ & Elected person \\
\hline
\end{tabular}




\begin{tabular}{|c|c|c|c|c|}
\hline Benuwa & $\begin{array}{l}\text { 1. Andul Kadir bin } \\
\text { Bair (SAP)/ } 497 \\
\text { 2. Haji Hassan bin } \\
\text { Wahap (Calon } \\
\text { Bebas)/ } 257 \\
\text { 3. } \\
\text { Maskam bin } \\
\text { Haji Bakri } \\
\text { (Calon Bebas)/ } \\
\text { 11 }\end{array}$ & 36 & 926 & $\begin{array}{llll}\text { Abdul Kadir bin } & \text { Bair } \\
\text { (SAP) } & & & \end{array}$ \\
\hline Lada & 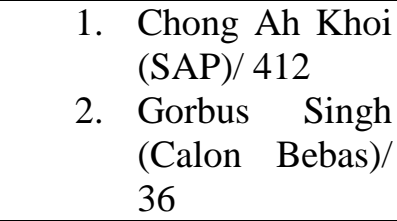 & 6 & 525 & Chong Ah Khoi (SAP) \\
\hline Layangan & $\begin{array}{ll}\text { 1. Abdullah bin } \\
\text { Anson (SAP)/ } \\
358 \\
\text { 2. Michael Kong } \\
\text { Su Chen (Calon } \\
\text { Bebas)/ } 37\end{array}$ & 14 & 528 & $\begin{array}{l}\text { Abdullah bin } \text { Anson } \\
\text { (SAP) }\end{array}$ \\
\hline Kubong & \begin{tabular}{llr} 
1. & \multicolumn{2}{l}{ Koh Kian Poh } \\
(Calon & Bebas)/ \\
& 73 & \\
2. & Suhaili & bin \\
& Israil & (SAP)/ \\
& 213 & \\
\end{tabular} & 14 & 338 & Suhaili bin Israil (SAP) \\
\hline Lajau & $\begin{array}{ll}\text { 1. Simon Chung } \\
\text { Thien Min } \\
\text { Calon Bebas)/ } \\
90 \\
\text { 2. Haji Ali bin } \\
\text { Green (SAP)/ } \\
216 \\
\text { 3. Mahmud bin } \\
\text { Ahmat (Calon } \\
\text { Bebas)/ } 81 \\
\end{array}$ & 2 & 489 & Haji Ali bin Green (SAP) \\
\hline Ramsay & $\begin{array}{ll}\text { 1. } & \text { Joseph Mathew } \\
& \text { Elias Daud } \\
& (\mathrm{SAP}) / 107 \\
\text { 2. } & \mathrm{Ng} \mathrm{Ah \quad Kiew} \\
& \text { (Calon Bebas)/ } \\
& 181 \\
\end{array}$ & 14 & 413 & $\begin{array}{l}\mathrm{Ng} \text { Ah Kiew } \\
\text { Bebas) }\end{array}$ \\
\hline Victoria & $\begin{array}{llr}\text { 1. } & \text { Lucas } & \text { Kong } \\
& \text { Thiam } & \text { Sinn } \\
& \text { (Calon } & \text { Bebas)/ } \\
& 209 & \\
\text { 2. } & \text { Bernard } & \text { Leong } \\
& \text { Thien } & \text { Pui } \\
& \text { (BUNAP)/ } 664 \\
\end{array}$ & 34 & 1,159 & $\begin{array}{l}\text { Bernard Leong Thien Pui } \\
\text { (BUNAP) }\end{array}$ \\
\hline $\begin{array}{l}\text { Lapangan } \\
\text { Terbang }\end{array}$ & $\begin{array}{l}\text { Charlie Yong Nyuk Kui } \\
\text { (BUNAP) }\end{array}$ & - & - & $\begin{array}{l}\text { Charlie Yong Nyuk Kui } \\
\text { - Diisytiharkan dilantik }\end{array}$ \\
\hline
\end{tabular}

Sumber: Dipetik dan diubahsuai daripada Colony of North Borneo Government Gazette, 1 Mac 1963, hlm. 142. 
Berdasarkan Jadual 2, masyarakat peribumi Islam berperanan penting dan terlibat dalam pilihan raya ke arah berkerajaan sendiri di Labuan. Seperti yang dapat dilihat daripada jadual, Abdul Kadir bin Bair menguasai ward Benuwa, Abdullah Bin Anson untuk ward Layangan, Suhaili Bin Israil untuk ward Kubong dan Haji Ali bin Green untuk ward Lajau. Ward yang lainnya seperti ward Lada, Ramsay, Victoria dan Lapangan Terbang didominasi oleh orang-orang Cina. Meskipun jumlah perwakilan keseluruhan peribumi Islam adalah lebih sedikit daripada etnik Cina, jumlah kemenangan yang didominasi oleh peribumi Islam menunjukkan penglibatan peribumi Islam ini memberikan kepentingan dalam pilihan raya yang pertama di Labuan. (Tidak termasuk ward Lapangan Terbang kerana Charlie Yong Nyuk Kui menang tanpa bertanding, kerana dilantik.) Sabah Alliance Party (SAP) (gabungan: UNKO, USNO, dan BUNAP) telah mendominasi pemerintahan di Labuan dengan kemenangan majoriti.

Menilai tahap penglibatan masyarakat peribumi Islam dalam politik secara keseluruhan, dapat dikenal pasti bahawa peribumi Islam di Labuan terlibat dalam kesemua tahap penglibatan politik sepertimana yang dihuraikan oleh Rush (1992) iaitu bermula daripada memegang jawatan dalam organisasi politik, bertanding jawatan dalam organisasi politik, ahli aktif organisasi politik, ahli aktif quasi atau separa organisasi politik, terlibat dalam aktiviti politik seperti mesyuarat atau rapat umum, ahli tidak aktif organisasi politik, ahli tidak aktif quasi atau separa organisasi politik, terlibat dalam perbincangan politik yang tidak formal, mempunyai sedikit minat dalam politik dan mengundi. ${ }^{23}$

\section{Kedudukan Politik Peribumi Islam di Labuan Semasa Penjajahan British}

Berdasarkan huraian penglibatan dan sekaligus peranan masyarakat peribumi Islam di Labuan dalam politik, khususnya dalam aktiviti berpersatuan, tuntutan kemerdekaan dan penubuhan Malaysia serta keterlibatan dalam pilihan raya umum tempatan, British ternyata memberikan respon yang baik (supportive) dan terbuka kepada peribumi Islam melibatkan diri dalam politik. British memberikan golongan ini kebebasan untuk melibatkan diri dan menyuarakan hak-hak mereka dalam menuntut sebarang ketidakadilan terhadap mereka. Namun, kebebasan dan kedudukan mereka dalam politik ini sebenarnya berada pada tahap tertentu yang dikawal oleh British. Tahap kebebasan tersebut adalah berdasarkan kepada agenda dan kepentingan British di Labuan iaitu agar kegiatan-kegiatan ini tidak akan menjejaskan kepentingan atau melebihi kekuasaan politik British di Labuan. Tingkah laku British yang memberikan peluang keterlibatan penduduk peribumi dalam politik, namun menghadkan tahap penglibatan ini ada kaitannya dengan dasar dekolonisasi ${ }^{24}$ dan objektif pentadbiran dan pemerintahan British di tanah jajahan selepas Perang Dunia Kedua.

Selepas tamatnya Perang Dunia Kedua, dasar dekolonisasi telah dilaksanakan di kesemua tanah jajahan di dunia, termasuklah tanah-tanah jajahan British. Dasar Dekolonisasi ini merupakan usaha Pertubuhan Bangsa-Bangsa Bersatu (PBB) atau United Nations (UN) dalam mengembalikan kedaulatan wilayah-wilayah jajahan, dan termaktub dalam The Charter of the United Nations, Bab XI, dalam Artikel 73 dan $74 .{ }^{25}$ Artikel tersebut telah menggariskan prinsip-prinsip dan usaha dalam proses dekolonisasi. Antaranya adalah pemberian kerajaan sendiri kepada penduduk tempatan. Secara ringkas, dekolonisasi merupakan satu proses yang berlaku selepas Perang Dunia Kedua, yang melibatkan pembebasan negara-negara jajahan daripada negara-negara penjajah, menjadi satu negara yang mana pentadbiran dan segala aspek di dalam negara tersebut diterajui semula oleh peribumi, sepertimana yang telah dinyatakan oleh Zag (2006: 20):

"Decolonization is the ending of colonialism and the liberation of the colonized. This requires the dismantling of the colonial government and its entire social system upon which control \& exploitation are based. Decolonization, then, is a revolutionary struggle aimed at transforming the entire social system and reestablishing the sovereignty of tribal peoples, In political terms, this means a radical de-centralization of national power (i.e., the dismantling of the nation-state) and the establishment of local autonomy." 
Merujuk daripada maksud dekolonisasi ini, jelas bahawa dasar pemerintahan British semenjak tahun 1946 di Labuan adalah tertumpu kepada penyediaan berkerajaan sendiri kepada penduduk peribuminya. Selepas Perang Dunia Kedua, pihak British telah menyediakan peluang yang lebih besar kepada penduduk peribumi untuk terlibat dalam pentadbiran dan politik berbanding zaman sebelum tahun 1946 berikutan perubahan yang berlaku pada objektif pentadbiran British di tanah jajahan. Objektif pentadbiran pada zaman sebelum Perang Dunia Kedua iaitu semasa Sabah dalam pentadbiran Syarikat Berpiagam Borneo Utara (SBBU) tertumpu untuk mendapatkan keuntungan dan kepentingan British semata-mata. Namun, dengan adanya dasar dekolonisasi selepas perang, objektif pentadbiran tersebut telah mengalami perubahan seperti berikut (Kitingan \& Ongkili, 1989: 161)

1. Menyediakan kerajaan sendiri kepada penduduk tempatan.

(To provide a government; ie. to rule.)

2. Melindungi kepentingan British dan pelabur Eropah di tanah jajahan.

(To protect the British and European interests and investments in the region.)

3. Memberikan perkhidmatan kepada pasaran di Britain.

(To service the home markets.)

4. Menyediakan perkhidmatan kebajikan awam dan sosial seperti kesihatan dan pendididkan.

(To provide some public and social services such as health and education)

5. Menjadikan Britain semakin unggul.

(To make Great Britain greater)

Melalui objektif-objektif ini, semakin ramai peribumi diberikan pos atau jawatan dalam jabatan-jabatan kerajaan yang ditubuhkan di Labuan, penubuhan Labuan Town Board yang dianggotai oleh peribumi, perundangan yang melibatkan institusi peribumi juga turut digubal dengan lebih berkesan daripada zaman-zaman sebelumnya. Begitu juga halnya dalam kegiatan berpolitik penduduk peribumi. ${ }^{26}$ Mereka diberikan peluang menubuhkan persatuan dan pertubuhan, namun, seperti yang telah sedia maklum, British mengehadkan kedudukan peribumi dalam politik dan pentadbiran demi menjaga kepentingan British sendiri, khususnya untuk mencapai objektif pentadbiran bernombor 2, 3 dan 5 .

Antara contoh aktiviti persatuan adalah terhad dengan kepentingan British adalah apabila PKML telah dibubarkan atas alasan akronim persatuan tersebut iaitu 'P.K.M' menyerupai Parti Komunis Malaya di Tanah Melayu dan slogan 'merdeka' oleh PKML juga seakan-akan mencabar pendudukan dan kekuasaan British di Labuan (Aziz, 2005). Parti Rakyat Labuan (PRL) yang ingin ditubuhkan pada tahun 1962 juga telah dibubarkan atas sebab perjuangannya yang dianggap "radikal" kerana membawa ideologi perjuangan Parti Rakyat Brunei (Singh, et al., t.t.). Calon yang bertanding dalam pilihan raya umum tempatan juga haruslah individu yang diperkenankan oleh British, yang biasanya berdarah kacukan Barat dan golongan yang berpendidikan Inggeris. ${ }^{27}$ Pemimpin-pemimpin peribumi Islam juga tidak mempunyai kuasa dalam membuat keputusan.

Di samping itu, kedudukan peribumi Islam dalam politik yang diberikan tidak semestinya merupakan keistimewaan yang dirasai oleh segenap lapisan masyarakat peribumi Islam, terutamanya daripada golongan bawahan yang merupakan masyarakat terbanyak. Keistimewaan yang diperolehi juga tidak meliputi aspek lain seperti ekonomi. Dari segi ekonomi, kedudukan peribumi Islam di Labuan lebih mundur berbanding etnik-etnik bukan peribumi dan imigran. ${ }^{28}$ Oleh yang demikianlah munculnya persatuan-persatuan yang memperjuangkan kepentingan agama dan bangsa seperti PML, PKML, BARIP Labuan dan Angkatan Desa. 


\section{KESIMPULAN}

Huraian penglibatan masyarakat peribumi Islam dalam politik di Labuan menunjukkan bahawa peranan dan tugas mereka dalam politik adalah merangkumi pemegang amanah dalam menjaga kebajikan orang-orang Islam dengan menggunakan kuasa 'politik' melalui aktiviti berpersatuan, menyertai pilihan raya tempatan dan terlibat dalam tuntutan kemerdekaan. Golongan peribumi Islam ini sesungguhnya diberikan peluang untuk terlibat dalam aktiviti berpersatuan seperti dalam PKML, PML, BARIP Labuan dan Angkatan Desa. Namun, segala aktiviti persatuan-persatuan tersebut sentiasa dikawal oleh British agar tidak melebihi kuasa politik atau menjejaskan kepentingan British di Labuan. Tingkah laku British ini ada kaitannya dengan dasar dekolonisasi dan objektif pentadbiran dan pemerintahan British selepas era perang Dunia Kedua, seperti yang telah dibincangkan. Kewujudan parti-parti politik seperti UNKO Labuan, USNO Labuan, BUNAP dan SAP menjelang tahun 1962 merancakkan lagi perkembangan politik ke arah kemerdekaan Labuan apabila wujudnya pilihan raya dan aktiviti berkumpulan (group activity) oleh komuniti peribumi Islam sehingga akhirnya Labuan merdeka di dalam Sabah ketika menyertai Persekutuan Malaysia pada tahun 1963. Kajian ini memberikan kepentingan kepada negara, bidang ilmu pengetahuan itu sendiri dan kepada masyarakat. Kajian merupakan salah satu cara untuk menghargai khazanah dan warisan negara. Labuan merupakan salah satu wilayah Persekutuan yang penting dan sebuah pulau bebas cukai yang sangat strategik kedudukannya dalam menjamin sosio-ekonomi negara. Selain itu, kajian juga dapat mengisi kelompangan sejarah Labuan, khususnya sejarah politik masyarakat tempatan Labuan pada peringkat awal, yang fokus kepada penduduk majoriti, iaitu peribumi Islam. Masih banyak maklumat berkenaan dengan Labuan yang belum didokumentasikan sehingga ke hari ini. Hasil kajian secara tidak langsung turut menyumbang kepada pensejarahan Malaysia dan perkembangan ilmu pengetahuan. Kajian terhadap Labuan ini juga akan menjadi panduan dan rujukan yang penting di masa hadapan sama ada dalam bidang politik, pentadbiran, sosial, pendidikan mahupun ekonomi demi perkembangan negara. Penghasilan kajian juga akan dapat menyedarkan dan menginsafi penduduk Labuan terhadap kepentingan sejarah awal di Labuan. Penceritaan tentang sejarah awal politik yang turut mengaitkan masyarakat dan petempatan mereka akan mencungkil sejarah latar belakang keturunan dan nenek moyang penduduk jati Labuan. Hal ini dapat membina jati diri etnik-etnik yang ada di Labuan dan menanamkan semangat cinta kepada tanah kelahiran dan bangga terhadap keturunan masing-masing.

\footnotetext{
${ }^{1}$ Gold, Gospel dan Glory merujuk kepada motif yang ingin dicapai oleh para penjajah di wilayah atau kawasan imperialisme. "Gold" merujuk kepada kekayaan, "Gospel" untuk keagamaan, yang khususnya demi menyebarkan agama Kristian manakala "Glory" merujuk kepada martabat dan keagungan bangsa. Motif 3G ini muncul seiring dengan kemunculan The Age of Discovery (Zaman Penemuan) yang telah diistilahkan oleh para sejarawan Barat sebagai zaman di mana berlakunya kegiatankegiatan eksplorasi yang banyak dan kegiatan penerokaan serta pelayaran oleh pihak Barat dalam mencari laluan baru ke Timur. Kegiatan eksplorasi dan penerokaan yang didasari oleh motif 3G (Gold, Gospel, Glory) ini akhirnya membawa kepada penerokaan pihak Barat ke Asia, Amerika, Afrika, India dan seterusnya ke wilayah Oceania. Pada ketika ini jugalah pemetaan dunia juga giat dilakukan bersempena dengan penemuan wilayah-wilayah baru oleh para eksplorasi Barat. Portugal dan Sepanyol merupakan pihak pelopor terawal dalam menjalankan misi eksplorasi ke Timur ini. Huraian lanjut, rujuk, David Nicolle, The Crusades, Great Britain: Osprey Publishing limited, (2001), hlm. 223.
}

\footnotetext{
${ }^{2}$ Istilah peribumi juga turut merujuk kepada istilah 'native' atau 'anak negeri' yang terdapat di dalam Ordinan No. 12 1952Interpretation (Definition of Native) yang menjelaskan erti 'native'. Menurut ordinan tersebut, peribumi adalah 'anak negeri' atau 'penduduk asli' negeri Sabah. Rujuk, Siti Aidah Hj. Lokin, Perubahan Sosioekonomi dan Pentadbiran: Masyarakat Peribumi Sabah (1881-1963), Kota Kinabalu: Universiti Malaysia Sabah, (2007), hlm. xi.
}

${ }^{3}$ North Borneo Annual Report, North Borneo: Government Printing, (1952), hlm. 130.

${ }^{4}$ Arkib negara Brunei Darussalam, 2012. 
${ }^{5}$ Stephen R. Evans, et al., The History of Labuan (Victoria Island), Singapore: Opus Publications, (2007), hlm. 4. Lihat juga, Dievi@ Janet bt. Jilin, Aktiviti Pembinaan dan Kesan Terhadap Pembangunan Labuan, Latihan Ilmiah Kejuruteraan Awam, Universiti Teknologi Malaysia, (2005), hlm. 7-9.

${ }^{6}$ Sumber Lisan daripada temu bual terhadap Puan Hajah Fauziah Binti Mohd Din Jaafar pada 14 November 2014, Wilayah Persekutuan Labuan. Rujuk juga Ranjit Singht, et al., Labuan Report: Chapter 7: Labuan, 1946-1963. Disimpan di Muzium Wilayah Persekutuan Labuan, Wilayah Persekutuan Labuan, (t.t).

${ }^{7}$ Sumber Lisan daripada temu bual terhadap Ybhg. Datuk Haji Isli Bin Haji Siput pada 11 November 2014, Wilayah Persekutuan Labuan.

${ }^{8}$ Rujuk senarai responden temu bual pada bahagian Bibliografi.

${ }^{9}$ C.O. 947/3, Commission Minutes and Hearings, hlm. 24-25; C.O. 947/21, Supplementary Documents North Borneo, hlm. 233.

${ }^{10}$ Ibid.

${ }^{11}$ C.O 947/21, Supplementary Documents North Borneo, hlm. 237; C.O. 947/3, Commission Minutes and Hearings, hlm. 24; C.O. 947/30, Surat-surat daripada badan-badan Pertubuhan Sabah Mengenai Cadangan Rancangan Malaysia, 1962, hlm. 911; C.O. 947/25, Labuan, hlm. 3-4.

${ }^{12}$ C.O. 947/3, Commission Minutes and Hearings, hlm. 22.

${ }^{13}$ Surat khabar Borneo Times, 4 September 1962, hlm. 4.

${ }^{14}$ C.O. 947/27, North Borneo Written Submissions Originals, hlm. 121.

${ }^{15}$ C.O. 947/3, Commission Minutes and Hearings, hlm. 22.

${ }^{16}$ C.O. 947/22, Commission of Enquiry Programme, hlm. 59; C.O. 947/3, Commission Minutes and Hearings, hlm. 23 ; C.O. 947/25, Labuan, hlm. 10-11.

${ }^{17}$ C.O. 947/3, Commission Minutes and Hearings, hlm. 22-23.

${ }^{18}$ C.O. 947/21, Supplementary Documents North Borneo, hlm. 236.

${ }^{19}$ C.O. 947/3, Commission Minutes and Hearings, hlm. 24.

${ }^{20}$ North Borneo News and Sabah Times, 18 April 1962, hlm. 1.

${ }^{21}$ Ibid.

22 Sebanyak lapan perjumpaan telah diadakan oleh IGC antara 30 Ogos hingga 26 November 1962. Pihak Sabah mengemukakan "Twenty Points" (Perkara 20) yang bertujuan memelihara dan menjamin hak dan kepentingan penduduk masa depan negeri Sabah dalam Malaysia. "Twenty Points" ini diluluskan dalam Majlis Perundangan pada Mac 1963 dan sedikit banyak telah mengurangkan kebimbangan penduduk dan pemimpin-pemimpin Sabah tentang masa depan Sabah dalam Malaysia. Rujuk, Ranjit Singh, et al., Labuan Report: Chapter 7: Labuan, 1946-1963. Disimpan di Muzium Wilayah Persekutuan Labuan, Wilayah Persekutuan Labuan, (t.t).

${ }^{23}$ Michael Rush mendefinisikan penglibatan politik atau political participation sebagai penglibatan individu di pelbagai peringkat aktiviti dalam sistem politik sama ada secara langsung atau tidak langsung. Penglibatan politik juga boleh dilihat dalam konteks penglibatan individu menyokong dasar-dasar kerajaan atau sistem politik. Kumpulan atau individu boleh mencapai objektif atau matlamat yang ingin diperolehinya melalui penglibatan politik yang lebih aktif. Rujukan lanjut, rujuk Michael Rush, Politics and Society: An Introduction to Political Sociology, (1992), London: Harvester Weatsheaf.

${ }^{24}$ Dasar Dekolonisasi (yang sudah diserap masuk dalam objektif pentadbiran dan pemerintahan British di tanah-tanah jajahan selepas Perang Dunia Kedua) oleh Persatuan Bangsa-Bangsa Bersatu (PBB) atau United Nations (UN) telah menyarankan agar kesemua wilayah-wilayah jajahan Barat dibebaskan dan diberikan semula kepada peribumi tempatan untuk mengendalikan urusan pentadbiran dan pemerintahan (self-government) selepas era Perang Dunia Kedua. Dasar ini terpaksa diikuti oleh British sebagai salah satu daripada negara penjajah yang ada di dunia. Pada masa yang sama, British juga perlu menjaga dan menjamin kepentingan Great Britain itu sendiri. Oleh yang demikianlah, British mengambil tindakan untuk memberikan 'peluang' tetapi pada masa yang sama, mengawal tahap penglibatan tersebut.

${ }^{25}$ Decolonization and United Nations dalam < www.un.org/en/decolonization/history.shtml > Diakses pada 20 Julai 2015. 
${ }^{26}$ Sesungguhnya, semenjak era penguasaan Syarikat Berpiagam Borneo Utara (SBBU), sukar untuk melaksanakan pentadbiran dan pemerintahan tanpa melibatkan penduduk peribumi. Oleh yang demikianlah, seorang Ketua Peribumi (Native Chief) dilantik demi mengekalkan struktur sosial dan melancarkan pentadbiran kampung. District Council System telah diperkenalkan pada tahun 1915, yang turut merangkumi Ketua Peribumi sebagai salah satu pentadbir. Namun, peranan ketua peribumi yang dilantik tidak dilihat sebagai satu jawatan yang penting kerana lebih terarah kepada tanggungjawab "agama dan kebudayaan". Hanya selepas Perang Dunia Kedua, posisi ini lebih terarah kepada politik dan dianggap satu jawatan yang rasmi.

${ }^{27}$ Sumber Lisan daripada temu bual terhadap Puan Hajah Fauziah Binti Mohd Din Jaafar pada 14 November 2014, Wilayah Persekutuan Labuan.

${ }^{28}$ Sumber Lisan daripada temu bual terhadap Puan Hajah Fauziah Binti Mohd Din Jaafar pada 14 November 2014, Wilayah Persekutuan Labuan.

\section{Reference}

Ahmad, A. T. (2003). The Malay Muslims, Islam and The Rising Sun: 1941-45. Selangor: Malaysian Branch of The Royal Asiatic Society.

Ahmad, Z. (1983). Pertumbuhan Nasionalisme di Brunei 1939-1962. Jabatan Sains Politik. Bangi: Universiti kebangsaan Malaysia.

Aini, N. dan Mersat, N. I. (2008). Bumiputera Islam dalam Politik Sarawak (1963-2007). Kertas Kerja. Dibentangkan pada 27-28 Februari di Seminar Serantau Perkembangan Islam Borneo, anjuran Universiti Teknologi Mara, Sarawak.

Albaghdady, A. A. (2003). Organic Geochemistry and Petrology of The Sendimentary Sequence of Labuan Island Offshore Sabah, East Malaysia. Tesis Sarjana (M. Sc.). Universiti Malaya.

Ali, A. H. et al. (2000). Sabah dalam Perluasan Pasaran. Bangi: Universiti Kebangsaan Malaysia.

Ali, I. (2009). The Role and Contribution of the British Administration and the Capitalist in the North Borneo Fishing Industry, 1945-1963. Sosiohumanika 2(1).

Ashari, N. (1998/99). Pertumbuhan dan Perkembangan Pelabuhan Miri Sebagai Pelabuhan Minyak 1910-1963. Latihan ilmiah (B. A Hons). Jabatan Pengajian Asia Tenggara. Universiti Malaya.

Aziz, H. (t.t). Parti Politik USNO dan BERJAYA di Sabah 1961-1996. Tesis Sarjana. Kota Kinabalu: Universiti Malaysia Sabah.

Aziz, N. (2001). Labuan 1846-1963: Dari Pangkalan Semulajadi ke Pelabuhan Terancang. Universiti Malaya.

Aziz, H. et al. (2014). Metodologi Penyelidikan Sejarah. Kuala Lumpur: Freemind Horizons Sdn. Bhd.

Buyong, J. (1981). Seminar Perjuangan Peribumi Menentang Penjajahan di Sabah: Protes

Terhadap Nilai Barat. Dibentangkan di Seminar Sejarah dan Masyarakat Sabah, Kota

Kinabalu pada 12-16 Ogos 1981, Anjuran Yayasan Sabah, Kerjasama dengan Persatuan Sejarah Malaysia.

C.O. 144/38/2787/73, Colonial Estimates 30 ${ }^{\text {th }}$, December, 1873.

C.O. 874/222. Petition of Labuan Residents to Strait Settlements. 1902.

C.O. 144/1. Palmerstone kepada Admiralty, 24 Julai 1846.

C.O. 947/21. Supplementary Documents North Borneo.

C.O. 947/22. Commission of Enquiry Programme.

C.O. $947 / 25$. Labuan.

C.O. 947/27. North Borneo Written Submissions Originals. 
C.O. 947/3. Commission Minutes and Hearings.

Colonial Office List, C.O. 1949. London: Her Majesty's Stationery Office. Arkib Negeri Sabah. Colonial Office List, C.O. 1950. London: Her Majesty's Stationery Office. Arkib Negeri Sabah. Colonial Office List, C.O. 1955. London: Her Majesty's Stationery Office. Arkib Negeri Sabah. Colony of North Borneo Government Gazette. (Tarikh-tarikh terpilih)

Colony of North Borneo Second Supplement to the Government Gazzette. (Tarikh-tarikh terpilih)

Colony of North Borneo Third Supplement to The Government Gazzette. (Tarikh-tarikh terpilih)

CSO. 2311/46/ 108. Secretariat File: Departmental Staff List 1958. Arkib Negeri Sabah.

CSO. 2311/46/ 108. Secretariat File: Departmental Staff List 1959. Arkib Negeri Sabah.

CSO. 2311/46/ 108. Secretariat File: Departmental Staff List 1960. Arkib Negeri Sabah.

CSO. 2311/46/ 108. Secretariat File: Departmental Staff List 1961. Arkib Negeri Sabah.

Dahaman, Y. A. (1992). Pentadbiran Undang-Undang Islam di Wilayah Persekutuan Kuala Lumpur dan Labuan. Universiti Malaya.

Danin, N. (1990/91). Tesi. Sejarah Pentadbiran British di Pulau Labuan, 1846-1890. Bangi: Universiti Kebangsaan Malaysia.

Evans, S. R. et al. (2007). The History of Labuan (Victoria Island). Singapore: Opus Publications.

F.O. 12/4. Memorial Glasgow Chamber of Commerce kepada Aberdeen. 21 Mei 1846.

F.O. 93/16 (1).

Fic, V. M. (2003). From Majapahit And Sukuh to Megawati SukarnoPutri. India: Abhinav Publications.

Foong, K. E. (1998). A General Overview on Labuan, Malaysia's International Offshore Financial Centre. Masters Degree Thesis. t.t: University Putra Malaysia.

Foreign Office to Colonial Office (F.O.C.). 21 November 1889.

Gullick, J. M. (1958). The Indigenous Political System of Western Malaya. London: Athlone Press.

Hall, M. (2007). Labuan Story: Memoirs of A Small Island Near The Coast of North Borneo. Kuala Lumpur: Synergy Media.

Hamzah, A. B. (t.t). Development of the Native Chief Institution of Sabah. (t.p).

Ho, H. L. (2004). Malaysia Collaboration: Its Role in the Development of Political Parties in Sabah, 1961- 1963. dalam Mohd. Sarim Hj. Mustajab dan G. Anantha Raman (ed.), Sabah In The Malaysian Nation Building, Kota Kinabalu: University Malaysia Sabah Publication.

Ho, H. L. (2005). The Role of Malaysia Collaboration in The Development of Political Parties in Sabah, 1961- 1963 (dalam Bahasa Malaysia). Malaysia in History, Journal of Malaysian Historical Society, No. 33.

Ho, H. L. (2008). The Emergence of Awareness in Nationalism, Politics and Independence in Sabah and Sarawak (dalam Bahasa Malaysia). Purba, Journal of Malaysian Museum Society. No. 27.

Ho, H. L. (2012). Orang Cina dan Penglibatan dalam Politik di Negeri Sarawak. 1841-1963. Jurnal Jabatan Sejarah Universiti Malaya. No. 20.

Ho, H. L. Gagasan Malaysia: Satu Kajian Mengenai Peranannya terhadap Perkembangan Parti Politik di Sabah, 1961-1963. dalam Mohd. Sarim Hj. Mustajab dan G. Anantha Raman. (2003). Sabah dalam Konteks Pembinaan Nasion Malaysia: Prosiding Seminar Kebangsaan Pembinaan Nasion Malaysia. Kota Kinabalu: Universiti Malaysia Sabah.

Ho, H. L. Kesedaran Politik di Sarawak, 1930-1963. Jurnal Borneo-Kalimantan, Jurnal Antarabangsa Kajian Masyarakat, Budaya dan Sejarah Borneo-Kalimantan. 1(1). (2013). 
Ibrahim, N. (1997/98). Mengisi Ruang Sejarah: Provinsi Keppel 1877-1941. Latihan Ilmiah (B. A Hons). Jabatan Pengajian Asia Tenggara. Universiti Malaya.

Idris, H. (2007). Sabah dan Sarawak: Ke Arah Pembentukan Pelabuhan Moden di Malaysia dalam Abad ke-21. Borneo Research Journal. (1).

Ingleson, J. E. (1971). James Brooke and British Political Activities in Borneo and Sulu 18391868: Local Influences on the Determination of Imperial Policy. Borneo Research Bulletin. 3(1).

Irwin, G. (1955). Nineteenth Century Borneo: A Story in Diplomatic Rivalry. Singapore: Donald Moore Books.

Ishak, M. M. (1999). From Plural Society to Bangsa Malaysia: Ethnicity and Nationalism in the Politics of Nation Building in Malaysia. Tesis PhD. : The University of Leeds.

Islam, S. S. (2005). The Politics of Islamic Identity in Southeast Asia. Malaysia: Thomson Learning.

Ismail, A. R. dan Musa, M. (ed.). (2011). Akhbar dan Tokoh Persuratkhabaran Malaysia kurun ke-20. Pulau Pinang: Penerbit Universiti Sains Malaysia.

Jilin, D. (2005). Aktiviti Pembinaan dan Kesan Terhadap Pembangunan Labuan. Latihan Ilmiah Kejuruteraan Awam. Universiti Teknologi Malaysia.

Jipanus, M. (1987). District Administration in Sabah Pre-Independence, Kertas Kerja, Seminar Pentadbiran Daerah, Kudasang, Ranau, 23-25 November, anjuran Institusi Tadbiran dan Penyelidikan Sabah.

Jones, L. W. (2007). The Population of Borneo: A Study of The Peoples of Sarawak, Sabah and Brunei. Kota Kinabalu: Opus Publication.

Jusoh, R. (1998/99). Perjanjian Penyerahan Borneo Utara 1877-1902: Dari Ketuanan Sungai Bebas ke British North Borneo Company. Latihan Ilmiah (B. A Hons). Jabatan Pengajian Asia Tenggara. Universiti Malaya.

Kitingan, J. dan William, G. (1990). Development Of Administration System In Sabah Since Independence. Sabah: Institute For Development Studies.

Labansin, A. (t.t). Perkembangan Pasukan Polis di Sabah 1881-1942. Latihan Ilmiah: Universiti Malaya.

Labuan Annual Report. Tahun 1911.

Labuan Annual Report. Tahun 1922.

Labuan Official Gazette. Tahun 1901.

Laindri, N. (2013). Penglibatan Masyarakat Bugis dalam Politik dan Pentadbiran di Tawau, Sabah 1963-2012. Latihan Ilmiah. Kota Kinabalu: UMS.

Lapian, A. B. (1996). Peta Pelayaran Nusantara Dari Masa ke Masa. Jati. bil. 2. Disember.

Leong, C. (t.t.) Labuan: Past, Present and Future. Sabah: Sabah State Government.

Lo, H. H. (1988). Decolonization and Political Development in Hong Kong: Citizen Participation. Asian Survey. Vol. 28 (6). : University of California Press.

Lokin, S. A. (2007). Perubahan Sosioekonomi dan Pentadbiran: Masyarakat Peribumi Sabah (1881-1963). Kota Kinabalu: Universiti Malaysia Sabah.

Luping, H. J. (1985). The Kadazan and Sabah Politics. Tesis Sarjana. NZ: Victoria University of Wellington.

Luping, H. J. (1994). Sabah's Dilemma: The Political History of Sabah (1960-1994). Kuala Lumpur: Magnus Book.

Macfarlene, G. C. (2005). Labuan: Service with 1 Australian Beach Group. Australia: t. p.

Margaret, R. (1974). The Politics of Belonging: Political Change in Sabah and Sarawak. Kuala Lumpur: Oxford University Press.

Mat Zain., N. (1997/98). Persempadanan Air di Perairan Borneo Utara 1878-1930. Latihan Ilmiah (B. A Hons). Jabatan Pengajian Asia Tenggara. Universiti Malaya. 
Md. Nor, N. A. (1997/98). Elopura-Sandakan 1879-1963: Perdagangan dan Pelabuhan. Latihan ilmiah (B. A Hons). Jabatan Pengajian Asia Tenggara. Universiti Malaya.

Md. Shah, S. K. (1995). Sejarah Pertahanan Pulau Singapura dan Wilayahnya, 1819-1927. Tesis Sarjana (M. A). Jabatan Pengajian Asia Tenggara. Universiti Malaya.

Mentua, W. (2011). Tokoh Peribumi Daerah Kota Belud, Sabah: OKK Datuk Golkhan bin Hasbullah (1947-2009). Latihan Ilmiah. Kota Kinabalu: UMS.

Minit-Minit Mesyuarat Persatuan Melayu Labuan (PML) Tahun 1956 sehingga Tahun 1961.

Mohd. Ariff, M. R. (1995). Dari Pemungutan Tripang Ke Penundaan Udang: Satu Kajian Mengenai Sejarah Perikanan di Borneo Utara 1750-1990. Kuala Lumpur: Penerbit Universiti Malaya.

Muhiddin, Y. (1990). Islam di Sabah. Kuala Lumpur: Dewan Bahasa dan Pustaka.

Munip, A. M. (1984). Bandar Maharani dan Daerah Muar 1884-1920: Peribumi dan Permodenan. Jabatan Sejarah Universiti Malaya, Kuala Lumpur: United Selangor Press Sdn. Bhd.

Mustaffa, N. Z. (1998/99). Provinsi Dent 1877-1941: Dari Kesultanan Melayu Kepada Pedagang ke Company. Latihan Ilmiah (B.A Hons). Jabatan Pengajian Asia Tenggara. Universiti Malaya.

Norbert, C. (2010). Institusi Pentadbiran Peribumi Daerah Tambunan, 1963-2006. Latihan Ilmiah. Kota Kinabalu: UMS.

North Borneo Annual Report 1947, Arkib Negeri Sabah.

North Borneo Annual Report 1948, Arkib Negeri Sabah.

North Borneo Annual Report 1949, Arkib Negeri Sabah.

North Borneo Annual Report 1950, Arkib Negeri Sabah.

North Borneo Annual Report 1955, Arkib Negeri Sabah.

North Borneo Annual Report 1956, Arkib Negeri Sabah.

North Borneo Annual Report 1957, Arkib Negeri Sabah.

North Borneo Annual Report 1958, Arkib Negeri Sabah.

North Borneo Annual Report 1959, Arkib Negeri Sabah.

North Borneo Annual Report 1960, Arkib Negeri Sabah.

North Borneo Annual Report 1961, Arkib Negeri Sabah.

North Borneo Annual Report 1962, Arkib Negeri Sabah.

North Borneo Annual Report 1963, Arkib Negeri Sabah.

North Borneo Government. (1963). Sabah Annual Report. North Borneo: Government Printing Department.

North Borneo News and Sabah Times, (18 April 1962).

Ongkili, J. P. (1972). Modernization in East Malaysia, 1960-1970, Oxford in Asia Current Affairs. : Oxford University Press.

Ooi, K. G. (2011). The Japanese Occupation of Borneo, 1941-1945. USA: Routledge Publisher.

Osman, S. (1981/82). D. J. Jardine and Native Administration in Sabah 1934-1937, Sabah Society Journal, VII (2).

Osman, S. (1985). Pentadbiran Peribumi Sabah 1881-1941. Kajian Etnografi Sabah Jilid 9.

Osman, S. (1987) Malay-Muslim Political Participation in Sarawak: 1952-1987. Institute of Southeast Asian Studies (ISEAS) Field Report Series, Singapore: ISEAS.

Osman, S. (1989). The Role of Governor D. J. Jardine in Improving the Welfare of the Indigenous People of Sabah 1934-37. Journal of Southeast Asian Studies. Vol. 20. (2).

Osman, S. et al. (1995). Sejarah Brunei Menjelang Kemerdekaan. Kuala Lumpur: Dewan Bahasa dan Pustaka. Kementerian Pendidikan Malaysia.

Padzil, R. (1998). Pembekalan Air Johor-Singapura, 1824-1968. Tesis Sarjana (M. A). Jabatan Pengajian Asia Tenggara. Universiti Malaya. 
Phelan, P. R. (2003). The Traditional Legal System of Sabah. Kota Kinabalu: Pusat Kajian Borneo, Yayasan Sabah.

Salleh, B. H. \& Tan, L. (1996). Alam Pensejarahan Dari Pelbagai Perspektif. Kuala Lumpur: Dewan Bahasa dan Pustaka.

Singh, R. et al. (t.t.). Labuan Report: Chapter 7: Labuan, 1946-1963. Disimpan di Muzium Wilayah Persekutuan Labuan, Wilayah Persekutuan Labuan.

Report From The Select Comitee On Army And Ordinance Expenditure. (1850). (BPPB). Vol. I.

Robert, M. (1976). Native Courts and the Institution of Native Chiefs in Sabah: Kertas Kerja. Universiti Malaya.

Rogers, M. L. (1993). Local Politics in Rural Malaysia: Patterns of Change in Sungai Raya. Kuala Lumpur: S. Abdul Majeed \& Co.

Rohia, R. (1993/94). Labuan 1846-1941: Perdagangan dan Pelabuhan. Latihan Ilmiah (B. A Hons). Jabatan Pengajian Asia Tenggara. Universiti Malaya.

Rush, M. (1992). Politics and Society: An Introduction to Political Sociology. London: Harvester Weatsheaf.

Sabah Times, (16 April 1984).

Said, S. (1985) Malay Politics in Sarawak (1946-1966). Singapore: Oxford University Press.

Schelander, B. (1998). Brunei: Abode of Peace. Hawaii: University of Hawai'i Press.

Shaffer, L. N. (1966). Maritime Southeast Asia to 1500. England: M. E. Sharpe Inc.

Shaifoodin, N. S. (2010). Latihan Ilmiah. Sejarah Pentadbiran British di Labuan, 1846-1963. Kota Kinabalu: Universiti Malaysia Sabah.

Sidek, A. (2007). The Mystic of Borneo: Kadayan. Kota Kinabalu: Borneo Publishers.

Singh, R. (1984). Brunei, 1839-1983: The Problems of Political Survival. Singapore: Oxford University Press.

Sullivan, A. et al. (ed.). (1981). Commemorative History of Sabah 1881-1981. Kuala Lumpur: Sabah State Government.

Sumber Lisan daripada temu bual pada 18 Februari 2014 terhadap Tuan Haji Osman Bin Matusin, Ketua Kampung Patau-Patau I, Wilayah Persekutuan Labuan.

Sumber Lisan daripada temu bual pada 19 Februari 2014 terhadap Encik Nordin bin Ahmad, Ketua Kampung Lubok Temiang, Wilayah Persekutuan Labuan.

Sumber Lisan daripada temu bual pada 19 Februari 2014 terhadap Tuan Haji Ladis Bin Haji Salleh, Wilayah Persekutuan Labuan.

Sumber Lisan daripada temu bual pada 20 Februari 2014 terhadap Tuan Haji Abdul Rahman Lamuddin, Wilayah Persekutuan Labuan.

Sumber Lisan daripada temu bual pada 6 November 2014 terhadap Encik Willie Teo, ahli Komuniti Masyarakat Wilayah Persekutuan Labuan, Wilayah Persekutuan Labuan.

Sumber Lisan daripada temu bual terhadap Datuk Haji Isli Bin Haji Siput pada 11 November 2014, Wilayah Persekutuan Labuan.

Sumber Lisan daripada temu bual terhadap Encik Arzmi Dulang, Pembantu Muzium Kanan, Jabatan Muzium Wilayah Persekutuan Labuan.

Sumber Lisan daripada temu bual terhadap Prof. Madya Dr. Ismail Ali pada 9 November 2014, Kota Kinabalu, Sabah.

Sumber Lisan daripada temu bual terhadap Puan Hajah Fauziah Binti Mohd Din Jaafar pada 14 November 2014, Wilayah Persekutuan Labuan.

Sumber Lisan daripada temu bual terhadap Tuan Haji Annuar Tan, Ahli Komuniti Masyarakat Wilayah Persekutuan Labuan, pada 5 November 2014, Wilayah Persekutuan Labuan.

Sumber Lisan daripada temu bual terhadap Tuan Haji Osman Mahali pada 17 November 2014, Wilayah Persekutuan Labuan. 
Sumber Lisan daripada temu bual terhadap YB Datuk Rozman Bin Datuk Haji Isli, Pengerusi Perbadanan Labuan pada 13 November 2014, Wilayah Persekutuan Labuan.

Tarsat, M. (2007). Institusi Pentadbiran Pribumi: Satu Kajian Mengenai Ketua Anak Negeri di Sabah, 1946-1990. Tesis Sarjana. Universiti Malaysia Sabah.

Treacher, W. H. (1891). British Borneo: Sketches of Brunai, Sarawak, Labuan and North Borneo. Singapore: Government Printing Department.

Virginia, H. dan Othman, N. (ed.). (2003). Malaysia: Islam, Society and Politics: essays in honour of Clive S. Kessler. Singapore: Institute of East Asian Studies.

Warren, J. F. (2007). The Sulu Zone 1768-1898: The Dynamics od External Trade, Slavery, and Ethnicity in The Transformation of A Southeast Asian Maritime State(2 ${ }^{\text {nd }}$ ed.). Singapore: National University of Singapore Press.

Wilson, R. A. M. (1994). A Cargo of Spice or Exploring Borneo. London: Radcliffe Press.

Wong, T. K. (2004). Community and Society. Kota Kinabalu: Natural Publication (Borneo).

Yap, H. P. (1958). The Founding of Labuan, Latihan Ilmiah (B.A. Hons). Jabatan Sejarah, Universiti Malaya.

Yunos, Y. (1997/98). Hubungan Perdagangan Pelabuhan Kuching Dengan Singapura 19001963. Latihan Ilmiah (B. A Hons). Jabatan Pengajian Asia Tenggara. Universiti Malaya.

Yusin, S. (2009). Sejarah Penyertaan Pemimpin Islam Di Dalam Parti UPKO dan PBS (19611994). Latihan Ilmiah. Kota Kinabalu: UMS. 